\title{
Osmanlı Devleti'nde Yeteri Kadar Bilinmeyen Bir Proje: Abdurrahman Ağa’nın 1700 (H.1111) Tarihli Gemi İnşa Faaliyeti ve Bazı Değerlendirmeler
}

\author{
Süleyman Polat ${ }^{*}$
}

\begin{abstract}
$\ddot{O ̈}_{z}$
Tarih boyunca Birecik, Fırat üzerinden Basra'ya yapılan nehir taşımacılığında önemli bir yere sahipti. Bu önemli yeri Osmanlı hâkimiyetine girmesinden sonrada devam etmişti. Özellikle Osmanlı devrinde bölgede vuku bulan çatışmalarda, Birecik'ten askerî taşımacılık yapılmak maksadıyla gemi inşa talepleri payitahttan gelmişti. Bununla beraber Osmanlı hâkimiyetine geçmesinden XVIII. yüzyıla kadar, Birecik'te gerçekleşen gemiinşa faaliyetlerininhiçbiri Abdurrahman Ağa'nınüstlendiğiprojekadar teşkilatlı ve büyük değildi. Ne var ki, Abdurrahman Ağa'nın gerçekleştireceği projenin büyüklüğü inşa edeceği gemilerin sayısından değil, ebatlarından kaynaklanmaktaydı. Bu çalışmada dikkat çekici bir süreç olan Abdurrahman Ağa'nın yürüttüğü gemi inşa faaliyetlerine, bizzat mübaşeretliğinde tutulan muhasebe defterleri üzerinden detaylı bir inceleme yapılacaktır. Böylece Osmanlı'nın doğusunda Fırat'a kıyısı olan bir kazada, inşa edilen bir nehir donanma işinin ayrıntıları ortaya konulacaktır. Fakat bundan daha önemlisi, bu esnada ortaya çıan verilerin derinlemesine analizi yapılarak, kritik bir zamanda niçin Abdurrahman Ağa mübaşeretinde bu projenin icrasına çalışıldığı irdelenecektir. Ayrıca inceleme sonucunda ortaya çıkan verilerin kıyaslanmasıyla, Birecik'teki gemi inşa faaliyetlerinin tarihsel süreçteki gelişimi ve Birecik Tersanesi'nin bu zaman dilimindeki yeri değerlendirilecektir.
\end{abstract}

Anahtar Kelimeler: Osmanlı Nehir Donanması, Birecik, Abdurrahman Ağa, Firkata, Firat Nehri.

* Doç. Dr., Ankara Hacı Bayram Veli Üniversitesi, Edebiyat Fakültesi, Tarih Bölümü, Ankara/TÜRKIYE, suleymanpolat_@hotmail.com, ORCID: 0000-0002-1939-7293. DOI:

Makale Gönderim Tarihi:1 1.02.2019 - Makale Kabul Tarihi: 09.01.2020 


\title{
A Not Well-Known Project in the Ottoman State: Abdurrahman Ağa's Shipbuilding Activity in 1700 (Ah.1111) and Some Evaluations
}

\begin{abstract}
Throughout history, Birecik occupied an important place in river transport on the Euphrates to Basra. It maintained this important position after coming under the rule of the Ottomans. Particularly in the conflicts taking place in the region during the Ottoman period, shipbuilding demands came from the capital city for the purpose of military transport from Birecik. However, from falling under the Ottoman rule until the $18^{\text {th }}$ century, none of the shipbuilding activities in Birecik was as organised and big as the project undertaken by Abdurrahman Ağa. The greatness of Abdurrahman Ağa's project did not stem from the number of ships to be built, but their size. This study provides a comprehensive examination of the shipbuilding activities undertaken by Abdurrahman A $\breve{g a}$, a remarkable process, on the basis of the ledgers he kept personally. Thus, the study presents the details of a river navy work in a district on the banks of the Euphrates in eastern Ottoman lands. But more importantly, the study provides an in-depth analysis of the data obtained in this process, and addresses the question of why the execution of this project was started by Abdurrahman A $\breve{g} a$ in such a critical time. Also by comparing the data gathered from the analysis, the study discusses the development of shipbuilding activities in Birecik in the historical process as well as the role of Birecik Shipyard in this period.
\end{abstract}

Keywords: Ottoman River Fleet, Birecik, Abdurrahman A ğa, Firkata, the Euphrates.

\section{Giriş}

Bugün Şanlıurfa iline bağlı Birecik, Fırat Nehri'nin sol kıyısında, etrafı yarım daire şeklinde dağlarla çevrilmiş bir mevkide kurulmuştur. Güneydoğu Anadolu'dan Suriye ve Mezopotamya'ya açılan önemli bir yol güzergâhının üzerindedir. Bu konumundan dolayı tarih boyunca stratejik bir öneme sahipti. Nitekim Birecik bulunduğu noktadan Suriye ve Mezopotamya'dan geçerek Basra'ya kadar uzanan mühim bir ticaret yoluna ev sahipliği yapmışt ${ }^{1}$. Birecik’i bu ticaret güzergâhında önemli kılan nokta, kara yolunu kullanan ticaret kervanlarının yanı sıra, Fırat üzerinden sallar yahut "kelek" ismi verilen gemilerle ticaretin nehir üzerinden de yapılabilmesiydi. Nitekim Fırat Nehri Toroslardaki sarp, engebeli arazideki akış

$1 \quad$ M. Streck, "Birecik”, İA., C. II, MEB Yay., İstanbul 1979, ss. 629, 631.

Belleten, Ağustos 2020, Cilt: 84/Sayı: 300; 623-666 
hızı yüksek ve dar geçitlerinden yol aldıktan sonra, Birecik’in kurulduğu noktadan başlayarak ulaşım için elverişli bir alanda seyrine devam etmekteydi. Bu durumdan dolayı M.Ö. 9. yüzyıllarda Asurlular devrinden itibaren Birecik'ten Mezopotamya'ya tulumlarla desteklenen basit sallarla, nehrin akış yönü doğrultusunda seyahat yapılmıştı ve bu durum Birecik tarihinin yakın zamanlarına kadar devam etmişti ${ }^{2}$.

Birecik 1516 Mercidabık savaşının akabinde Osmanlı hâkimiyetine girdi. Özellikle Kanuni Sultan Süleyman'ın Irakeyn seferinden (1533-1536) sonra Bağdat'ın Safevi Devleti'nden alınması ve Basra'ya kadar alanın Osmanlı kontrolüne girmesiyle birlikte, Osmanlı Devleti için daha önemli bir hale geldi. Gerek ticarî gerek askerî anlamda Birecik'ten Bağdat ve Basra'ya nehir yoluyla yapılan taşımacılık arttı. Nitekim Birecik Osmanlı devrinde kuzeyden Basra'ya uzanan nehir güzergâhında önemli bir iskeleye sahipti ${ }^{3}$. Bununla beraber Birecik'te askerî amaçlarla yapılan taşımacılık ve bu amaca yönelik gemi/tekne/sandal inşası dikkat çeken bir diğer husustu. Özellikle 16. yüzyılın ikinci yarısından itibaren Birecik’te gemi yapımıyla yahut gemi yapım talebiyle ilgili resmi kaynaklara yansımış istekler mevcuttu ${ }^{4} . \mathrm{Bu}$ istekler hususiyetle bölgede siyasi istikrarın bozulduğu süreçte, askerî bir operasyonun öncesinde vuku bulmuştu.

18. yüzyılın başlarında Birecik'te büyük çaplı ve dikkat çekici bir başka gemi yapımı faaliyeti gerçekleşmişti. Bu gemi yapım sürecini Abdurrahman Ağa organize etmişti. Abdurrahman Ağa'nın mübaşeretinde Birecik'te inşa edilen gemilerin bü-

2 Streck, a.g.m., ss. 629-630.

3 İdris Bostan “Birecik”, DİA, C. 6, TDV. Yay., İstanbul 1992, s. 188.

4 16. yüzyılın ikinci yarısından 18. yüzyılın başlarına kadar Birecik'te gemi yapımına dair örnekler için bkz. Cengiz Orhonlu-Turgut Işıksal, "Osmanlı Devrinde Nehir Nakliyatı Hakkında Araştırmalar Dicle ve Fırat Nehirlerinde Nakliyat", İstanbul Üniversitesi Edebiyat Fakültesi Tarih Dergisi, S. 17-18 C. XIII, s. 83, 92, 96-97; Ali Yılmaz, XVI. Yüznılda Birecik Sancağı, İstanbul Üniversitesi Sosyal Bilimler Enstitüsü, Yayınlanmamış Doktora Tezi, İstanbul 1996, ss. 169-176; Ali Yılmaz, "Birecik’te Gemi İnsası", Uluslararası Türk Denizcilik ve Piri Reis Sempozyumu $26-29$ Eylül 2013, Türk Denizcilik Tarihi Bildiriler, 6. Cilt, TTK. Yay., Ankara 2014, ss.102-110; Abdurrahman Sağırlı, “Cezâyir-i Irâk-ı Arab veya Şattü'l-Arab’ın Fethi -Ulyanoğlu Seferi- 1565-1571”, Tarih Dergisi, S. 41, İstanbul 2005, ss. 56-58; Tahsin Ünal, IV. Murat ve Băgdat Seferi, Berikan Yay., Ankara 2001, s. 57. Genellikle belgelerden aktarımlarla Birecik'teki gemi yapım taleplerine yer veren bu çalışmalar dikkatle incelendiğinde, inşa edilmesi istenen gemilerin askerî mühimmat ve asker nakli çerçevesinde kullanılması öngörülen gemiler/tekneler olduğu görülmektedir. Buna ilaveten ender de olsa askerî amaçlı gemi inşası istenmiş, ancak bu talepler sonuçsuz kalmıştı. Bkz. Cumhurbaşkanlığı Devlet Arşivleri Başkanlığı Osmanlı Arşivi (BOA), Mühimme Defteri (Bundan sonra MD), 3, s. 377. 
yük kısmı taşıma değil, muharebe amacıyla yapılmıştı. Nitekim inşa sürecindeki bu amaç farklılığı Abdurrahman Ağa'nın yaptırdığı gemilerin hem ebat olarak çok daha büyük olmasına, hem de inşa sürecinin daha masraflı ve komplike bir organizasyon olmasına sebep olmuştu. Anlaşılan Abdurrahman Ağa'nın yürütmekle vazifelendirildiği bu inşa işi Osmanlı Devleti’nin Birecik merkezli denediği bir gemi inşa projesiydi. Bu dikkat çeken faaliyetin temelindeki neden, bir iç karışıklığın bastırılması düşüncesiydi. Öyle ki II. Viyana kuşatmasıyla başlayan ve 1699 Karlofça Antlaşması'yla son bulan uzun savaş yıllarında Osmanlı Devleti’nin askerî, ekonomik ve idarî mekanizmaları oldukça yıpranmıştı. Bu sürecin doğal sonuçlarından biriyse ülkenin muhtelif sahalarında çıkan karışıklıklardı. Basra havalinde de Arap kabilelerinin Osmanlı otoritesini ve dolayısıyla bölgedeki istikrarı bozan faaliyetleri mevcuttu. Bu durum karşısında Karlofça'dan sonra Basra hattında Osmanlı yönetiminin ele aldığı ilk işlerden birisi, isyan eden bu kabileleri tekrar kontrol altına almaktı. Nitekim bu isyanın bastırılması için Birecik'te bir donanma inşa edilmesine karar verilmiştit ${ }^{5}$.

Abdurrahman Ăga'nın gemi inşa faaliyetlerine dair bilgiler dönemin hem kitabi kaynaklarında ${ }^{6}$ hem de arşiv kayıtlarında yer bulmuştu. Özellikle arşiv kayıtlarında -yazının ilerleyen aşamasında belirtileceği üzere- gemi inşa aşamasının hazırlık sürecinden gemilerin tamamlanıp donatılmasına kadar tüm süreci takip etme imkânı vardır. Bu arşiv vesikaları içerisinde Abdurrahman Ağa'nın marifetiyle tutulan ve gemilerin yapım aşamasına 1şı tutan iki defter kayda değer niteliktedir. Özellikle Osmanlı Arşivi’ndeki fonlardan biri olan Maliyeden Müdevver (MAD) tasnifinde yer alan 5433 nr.lı defter en dikkat çekenidir. Klasik maliye kayıtlarının tutuluş tarzıyla siyakat kullanılarak kaydedilmiş bu defter, 300 günlük gemi yapım sürecinin gelir ve özellikle masraflarını ayrıntılı bir biçimde ortaya koyan bir kayıttır. Vurgulandığı üzere, bu işe mübaşir olarak atanmış Abdurrahman Ağa'nın gözetiminde tutulmuş olması ve gemilerin yapım öncesinde verilen birtakım emirlerin uygulanıp uygulanmadığının takibinin yapılabilmesi bu defteri değerli kılan bir başka husustur. Defterde dönemin mali yazım kaideleriyle tutulan mufassal,

5 Mehmet Topal, "Bağdadlı Nazmî-zâde Murteza'nın İcmâl-i Sefer-i Nehr-i Ziyab Adlı Risalesine Göre Ziyab Seferi ve Nehirde Yapılan Düzenlemeler”, Göller ve Nehirler Sempozyumu Bildiri Kitabl, Kayseri 2015, s. 74. Orhonlu-Işıksal, a.g.m., ss. 97-98.

6 Anonim Osmanh Tarihi (1099-1116/1688-1704), Haz. Abdulkadir Özcan, TTK Yay., Ankara 2000, s. 154; Silâhdar Findıklılı Mehmed Ağa, Nusretnâme Tahlil ve Metin (1106-1133/1695-1721), Haz. Mehmet Topal, Sosyal Bilimler Enstitüsü Türkiyat Araştırmaları Enstitüsü, Yayınlanmamış Doktora Tezi, İstanbul 2001, ss. 444, 445. 
icmal kısımların ardından kısa bir nesih özet de bulunmaktadır. Mufassal ve icmal kısımlarda sistemli bir biçimde gemi yapım sürecinin aşamaları "mübâya'a", "ücûrât” gibi başlıklarla anlatılmıştır. Abdurrahman Ağga’nın 300 günlük gemi yapım sürecini benzer kayıt tutma teknikleri ve başlıklarıyla anlatan bir diğer defter, yine aynı arşivdeki Başmuhasebe (D.BŞM) tasnifinde yer alan 964 nr.lı defterde bulunmaktadır. D.BŞM 964 nr.lı defter, MAD 5433 nr.lı defterde yer alan bilgileri temelde tekrar etmektedir. Bu defterin, diğer defterden tek farkı icmal ve kısa nesih özet kısmının bulunmamasıdır. Başka bir ifadeyle MAD 5433 nr.lı defterde yer alan mufassal kayıtlar aynen bu defterde de yer almıştır. Nitekim bu durum Abdurrahman Ağa'nın gemi yapım faaliyetlerinin anlaşılmasında ilgili kaynakları ön plana çıkarmaktadır.

Dikkat çekici bir süreç olan Abdurrahman Ağa'nın gemi inşa faaliyetlerine, bahsedilen kaynakların bir kısmı kullanılarak yaptığımız çalışmadan önce de değinilmişti ${ }^{7}$. Bununla birlikte Abdurrahman Ağa'nın yürüttüğü faaliyetlere dair kay-

7 Mesela Cengiz Orhonlu (Bkz. Orhonlu-Işıksal, a.g.m., ss. 85-86.), İdris Bostan (Bkz. İdris Bostan, Osmanh Bahriye Teşkilâtr: XVII. Yüzynlda Tersâne-i Âmire, TTK Yay., Ankara 1992, s. 22.) gibi araştırmacılar ilgili tarihte gerçekleşen gemi inşa faaliyetlerinden kısaca bahsetmiști. Lakin bu araştırmalar Abdurrahman Ağa'nın gemi yapım çalışmasına -bahsedilen kaynakları derinlemesine değerlendirmeden çalışmalarının konsepti gereği- birkaç cümleyle yer vermişlerdi. Bunlar dışında konuyla ilgili daha kapsamlı bir başka çalışma Tahir Öğüt tarafindan "18 ve 19. Yy.'da Birecik Sancağında İktisadi ve Sosyal Yapı” adlı çalışması çerçevesinde yapılmıştı. (Çalışmanın tam künyesi için bkz, Tahir Öğüt, 18 ve 19. Yy.'da Birecik Sancağında Íktisadi ve Sosyal Yapı, TTK Yay, Ankara 2013.) Bu çalışmada "Birecik’te Tersane Faaliyetleri” başlığında genel olarak Abdurrahman Ağa'nın yürüttüğü faaliyetleri de içine alan geniş bir zaman dilimi içerisinde Birecik’teki gemi yapım sürecinden bahsedilmişti. Lakin ilgili çalışma oluşturulurken özellikle Abdurrahman Ağa'nın faaliyetleri dahilinde kullanılan ana kaynak Osmanlı Arşivi'nin Başmuhasebe tasnifinde bulunan, D.BŞM.TRE, $14598 \mathrm{nr} .1$ bir defter parçasına dayanmıştı. İlgili defter tanıtılan kaynaklardan farklı olarak Abdurrahman Ağa'nın inşa faaliyetlerine -muhasebe defterlerinde önce finans kaynağı, sonra mübâya'a, ücûrât gibi- sistemli başlıklar halinde yer vermemişti. Siyakatla tutulan diğer defterlerden farklı olarak nesihle tutulmuş bu defterde, gelirlerden hiç bahsedilmediği gibi, harcama kalemleri de anlaşılabilir, sistemli bir tasniften uzak karışı bir anlatımla yer almıştı. Tüm bunlar Öğüt’ün kaynak kullanımından doğmuş birtakım hatalara düşmesine neden olmuş ve bu hataların bir kısmı yeri geldiğinde dipnotlarda belirtilmiştir. Ancak daha vahim bir durum, Öğüt tarafindan temel kaynak olarak kullanılan bu defterin, tanıtılan arşiv kaynaklarıyla kıyaslandığında müsvedde bir kaynak olduğunun anlaşılmasıdır. Öyle ki harcama çerçevesinde belirtilen toplam rakam, tanıtılan muhasebe defterindeki toplam rakam ile uyuşmamaktadır. Tahir Öğüt'ün çalışmasına benzeyen ve son zamanlarda yayımlanan bir başka çalışma Tahir Sevinç’in “Osmanlı Devleti İdaresinde Birecik’te Gemi İnşası ve Birecik Tersanesinin Önemi” adlı bildiri metniydi. (Bildirinin tam künyesi için bkz, Tahir Sevinç, "Osmanlı Devleti İdaresinde Birecik’te Gemi İnşası ve Birecik Tersanesinin Önemi (17. ve 18. Yüzyllar)" İslâm Tarihi ve Medeniyetinde Şanlurfa: "Osmanh Belge ve Kaynaklarnda Urfa", C. IV, Şanlıurfa 2018, ss. 56-74.) Sevinç, yapısı gereği daha az hacimli olan çalışmasında, 
naklar iyi analiz edilmeden yahut doğru kaynak kullanılmadan yapılan çalışmalar neticesinde Birecik'te gemi inşa faaliyetleriyle ilgili birtakım genellemeler ortaya çıkmıştır. Nitekim çalışmada bahsedilen arşiv vesikaları -önceki çalışmalara nazaran- daha detaylı incelenerek Abdurrahman Ağa'nın yaptığı gemi inşa faaliyetleri ayrıntılarıyla ortaya konulacaktır. Böylece Firat Nehri'nde eşi nadir görülen bir donanma inşa süreci betimlenerek buradan elde edilen verilerin değerlendirilmesiyle Birecik'teki gemi inşa faaliyetlerine dair bilgiler yeniden yorumlanacaktır.

\section{1. İnşaat Öncesi Hazırlıklar: Fizibilite Çalışmaları, Malzeme ve İş̧ Gücü Temini}

Kutsal İttifak savaşlarının ardından Karlofça Antlaşması'nın imzalanmasının sonrasında Osmanlı yöneticileri devletin savaş nedeniyle ilgilenemediği yahut savaş nedeniyle ortaya çıkan diğer sorunlarıyla ilgilenmeye başlamışlardı. Basra ve Kurna taraflarında çıkan Arap isyanlarının bastırılması ve bölgenin güvenliğinin sağlanması bunlardan biriydi. Tabi ki bu doğrultuda yapılması gereken en önemli iş, askerî harekât kapsamında yapılacak hazırlıktı. Anlaşılacağı üzere bu askerî harekât çerçevesinde bir nehir donanması kullanılacaktı ve bu nehir donanmasının inşası, hazırlık aşamasının önemli bir merhalesini teşkil etmişti.

Yukarıda da ifade edildiği gibi, Osmanlı Devleti, Bağdat ve Basra'yı ele geçirdikten sonra, bu bölgeye yapılan gerek askerî harekâtlarda gerekse ele geçirilen yerlerin tahkimatında nehir taşımacılığı kullanılmış̧ı. Bununla beraber öncekilerden farklı olarak bu harekât sırasında daha kapsamlı bir gemi inşaat faaliyetine girişilmişti ve bu durum ciddi bir hazırlık gerektirmişti. Bahsedilen ciddi hazırlığın önemli nedenlerinden biri, uzun savaş yılları esnasında Fırat'ın su taşımacılığında önemli yeri olan kanalların bakımının ve tamirinin yapılmamış olmasıydı. $\mathrm{Bu}$ nedenden dolayı Fırat Nehri'nin güzergâhında bazı değişmeler olmuş, nehir, ana

\footnotetext{
Birecik tarihinden ve Birecik'teki gemi inşa faaliyetlerine genel olarak değinmesinin akabinde, 18. yüzyılın ilk yarısında vuku bulan 3 farklı gemi inşa sürecini ele almıştır. Bu doğrultuda konuya yaklaşımı ve izlediği metot, Öğüt'ün çalışmasındaki bahsedilen bölümle paralellik arz etmektedir. -Tıpkı Öğüt'ün çalışmasında olduğu gibi- Sevinç’in Birecik’teki gemi inşa faaliyetleriyle ilgili kıyaslamalı çalışması, sondajlama verilere dayanmaktadır. Bu nedenle Sevinç de Abdurrahman Ağa'nın gemi inşa faaliyetlerinden bahsetmiş olsa da, gemi inşa sürecini bütüncül bir biçimde, baştan sona ortaya koyamamıştır. Nitekim bildirisinde Sevinç, ana kaynak olarak nitelediğimiz muhasebe defterlerini yeterince analiz edip, değerlendirememiştir. Dahası ilgili kaynaklardan sondajlama verilerle oluşturduğu tablolarda Abdurrahman Ağa'nın gemi inşa sürecini anlaşllır hale getirmekten ziyade, bilgi kirliliğine yol açmış ve inşa faaliyetini kaynakların işaret ettiği gerçeklikten uzaklaştırmıştır. Öyle ki, Sevinç’in çalışmasında yer alan ve çalışmayla örtüşen yahut bahsedilen biçimde çelişen bu bilgiler dipnotlarda paylaşılacaktır.
} 
hattından ayrılarak tali yollardan seyrine devam etmiş, bazı noktalarda daralmalar, bazı noktalarda ise genişlemeler olmuş, gölcükler meydana gelmişti ${ }^{8}$. Bir diğer önemli nedense, yapılacak olan gemilerin niteliğinden kaynaklanmıştı. Normalde ticaret ve askerî taşımacılık için olağan olarak kullanılan kelek ve sandallardan daha büyük gemilerin inşası bu sefer öncesinde planlanmaktaydı. Tüm bu nedenler, gemilerin inşa faaliyeti başlamadan Fırat Nehri’nde bir fizibilite çalışması yapılmasını gerekli kılmışıı.

Frrat Nehri'nin durumunun belirlenmesi için öncelikle Rakka beylerbeyine ve Birecik kadısına bir hüküm gönderilmişti. Bu hükümde, öncelikle yapılacak gemilerin sayısından ve hangi özelliklerde planlandığından bahsedilmişti ${ }^{9}$. Buna göre 60 adet "donanma-yı hümayun sefinesi" yapılacaktı. Bu yapılacak olan gemilerin 20 tanesi firkate ${ }^{10}$ büyüklügünde, kalan 40 tanesi ise firkateden daha küçük ebatta planlanmıştı. Ancak bu ölçekteki firkatelerin -yani savaş gemilerinin- Fırat suyolunu kullanarak Birecik'ten Şattü'l-Arab'a ulaşıp ulaşamayacağı bilinmemekteydi. Nitekim bu hususun araştırılması, suyolunun özelliklerine göre gemilerin ebatlarının belirlenmesi, hangi teçhizat ve mürettebatla tahkim edileceğinin tespiti gerekliydi. Bu tespitler gemi inşa faaliyetlerinin başlamamasından evvel yapılacaktı. Ayrıca bu işin tespiti çerçevesinde, işten anlayan, "suyun ahvalini" bilen kişilerin tecrübelerinden faydalanılacaktı. Bu konuda gemi inşası işine nazır tayin edilen Halep Cizyedarı Abdurrahman ile gereği gibi istişare yapılması vurgulanmış ve ayrıca belirlenen kriterler doğrultusunda Abdurrahman Ağa'nın inşaat işine yardım etmesi istenmişti ${ }^{11}$.

Gemilerin inşa hazırlıkları çerçevesinde bir diğer hüküm, bu iş için nazır tayin edilen Halep sakinlerinden Abdurrahman'a gönderilmişti ve işe başlamadan önce birtakım hususların genel hatlarıyla altı çizilmişti. Öncelikle tembih edilen konu,

8 Topal, a.g.m., s. 76.

9 Sevinç, a.g.m., s. 59.

10 Osmanlı donanmasının çektiri sınıf en küçük savaş gemisidir. Bu özelliğinden dolayı ince donanma gemisi olarak nehirlerde de kullanılır. 10 ila 17 oturak arasında inşa edilen firkatelere boy ve genişliğine göre 80 ila 100 levent yerleştirilebiliyordu. Özellikle 17. yüzyllın sonu ve 18. yüzyılın başlarında fazla sayıda firkate inşası sağlanmıştı. Bu yoğun üretimin sebeplerinden biri ilgili dönemde Tuna donanması için firkate yapılmasıydı. Ayrıntılı bilgi için bkz. İdris Bostan, Kürekli ve Yelkenli Osmanl Gemileri, Bilge Yayım Habercilik Yay., İstanbul 2005, ss. 228-233; İdris Bostan, "Gemi Yapımcılığı ve Osmanlı Donanmasında Gemiler" Türk Denizcilik Tarihi, C. I, Editörler: İdris Bostan-Salih Özbaran, Deniz Basımevi Müdürlüğü Yay., İstanbul 2009, s. 332.

11 Cumhurbaşkanlığı Devlet Arşivleri Başkanlığı Osmanlı Arşivi (BOA), Cevdet Bahriye (Bundan sonra C.BH), 149/7106/9-1 (27 Eylül 1699/2 Rebî‘ülâhır 1111). 
inceleme yapacak kişilerin belirlediği şekilde gemilerin inşasının tamamlanmasıyd. Ancak bu inceleme yapılmadan önce gemi inşası için gerekli temel malzeme olan kerestenin temini için hazırlıklar yapması istenmişti. Bu doğrultuda Rakka, Halep, Maraş, Malatya ve Ayıntab bölgelerinden gerekli kerestenin temin etmesi Abdurrahman Ağa'dan talep edilmişti. Abdurrahman'a gönderilen yazıda, yapılacak harcamalar, iş takibi ve işin finansmanıyla ilgili de genel hatlarıyla direktifler mevcuttu. Gemi yapım nazırı Abdurrahman'a bu işin finansmanıyla ilgili birtakım gelirler tahsis edilmişti. Yapılacak masrafların tahsis edilen gelirlerden temin edilmesi belirtildiği gibi; yapılan ödeme, satın alma gibi her türlü işlemin müfredat defterine özenle kaydedilmesi emredilmişti ${ }^{12}$.

Gemilerin yapım hazırlıkları çerçevesinde, kereste temininin organizasyonu sürecinde Rakka valisine gönderilen hüküm dikkate değer ayrıntılar vermekteydi. Buna göre, gemiler için kereste temin yerlerinden biri olarak belirlenen Rakka'dan Birecik’e gönderilecek keresteler gelişigüzel bir biçimde temin edilmeyecek; öncelikle gemiler için uygun kerestelik ağaçların kesimi İstanbul'dan Abdurrahman Bey'in yanına gönderilen "dağ mimarı" olarak adlandırılan marangoz eşliğinde, yani uzman görevlinin istediği ağaçlardan ve gemi yapımı için uygun standartlarda ve ölçülerde yapılacaktı. Kesim yapılacak bu bölgeden hangi tür ağaç kullanılarak tahtaların nasıl temin edileceği de belirtilmişti. Rakka bölgesinden temin edilecek kereste "dut eşcârı"nın kesiminden sağlanacaktı. Eğer miri topraklardaki ve kırsal alanlardaki ağaçların kesimi kâfi gelmezse, dut ağacının yetiştirildiği bahçelerden yapılacak kesimlerle kereste temininin desteklenmesi istenmişti. Ancak bahçelerden yapılacak kereste temini, bahçe sahiplerinin rızası ve kesilen ağaçların ücretlerinin verilmesiyle yapılabilecekti. Bahçelerden kesilecek ağaçlar için özellikle "kuru" olması şartı vurgulanmıştı. Kesimi tamamlanan kerestelerin ise Fırat üzerinden Birecik'e nakledilmesi yine emirde belirtilmiş; bunun yanında taşıma için gerekli mekkâre ücretlerinin nazır tarafindan ödeneceği ifade edilmişti ${ }^{13}$. Kereste teminiyle ilgili benzer bir başka hüküm Malatya Sancakbeyi Rişvanzade Halil'e gönderilen hükümdü. Nitekim Malatya sancă̆ının Ereş nahiyesinde gemi yapımı için uygun kerestenin bulunduğu ve bu kerestelerin Göksu Nehri’nden Murat Suyu'na, oradan da Birecik'e kelek ve sandallarla naklinin kolay olduğunun öğrenildiği ifade edilmişti. Kerestelerin kesim işinin ise yine Abdurrahman’ın yanında

13 Aynı çerçevede Halep, Maraş ve Malatya'daki yetkililere de benzer hükümler gönderilmişti. BOA, C.BH, 149/7106/9-2 (27 Eylül 1699/2 Rebî́ülâhır 1111). 
olan marangozlar vasıtasıyla yapılacağı belirtilmişti ${ }^{14}$. Anlaşılacağı üzere her iki belgede geçen bazı ayrıntılar Birecik'teki gemi inşa faaliyetleriyle ilgili bir çıkarım yapmamıza olanak sağlıyordu. Buna göre, gemi inşası için kereste sağlayan olağan bölgelerden bu süreçte yine kereste talebinde bulunulmuştu. Ancak kereste kesiminin Abdurrahman'ın yanından gönderilen marangoz ve mimarlar marifetiyle yapılması istenmişti. Nitekim bu ifadelerden Birecik'te yapılan gemilerin belgelerde belirtilen firkateler gibi büyük çaplı gemiler olmadığı anlaşılmaktaydı.

İnşa öncesi hazırlık sürecinde, özellikle temini vurgulanan ve finansmanı için belirlenen bütçenin dışından sağlanan kaynakla tedarik edilmeye çalışılan bir diğer malzeme demirdi. Öyle ki gemi yapımı için gereken demirin Adana eyaletinden sağlanması planlanmıştı. Adana beylerbeyine gönderilen emirde, gemi yapımı için gerekli demirin Adana'da çıkartılan demirden ve eyaletin mukataa gelirleri kullanılarak Abdurrahman'a göndermesi istenmişti. Henüz gemi yapım malzemelerinin nereden nasıl toplanacağının planlaması devam ettiğinden ve gemilerin ebatları belirlenmediğinden ne kadar demir talep edildiği belirtilmemişti. Ancak temin edilip gönderilecek demirin finansmanın nasıl sağlanacağı ana hatlarıyla izah edilmişti. Buna göre, Adana beylerbeyi çıkartılan demir için önce mekkâre davarlarını ayarlayacak, daha sonra hem demirin hem de mekkârenin masraflarını uhdesinde olan Adana muhassıllığı malından ödeyerek Birecik'e gönderecekti ${ }^{15}$.

Gemi inşa organizasyonun planlamaları dâhilinde, kurşun, katran, yelken bezi gibi mühimmatın tedariki önemli bir başka husustu. Bu çerçevede Halep, Diyarbakır, Maraş, Ayıntab, Malatya, Rakka beylerbeyi, sancakbeyi yahut valilerine, bölgedeki kadılara ve diğer görevlilere ayrı ayrı emirler gönderilmişti. Görevlilerden istenen; gemi inşa görevine nazır tayin edilen Abdurrahman’ın gönderdiği defter mukabilinde, her ne talep edilmişse satın alınıp, kiralanan mekkârelere

BOA, C.BH, 149/7106/7 (12 Ekim 1699/17 Rebî‘ülâhır 1111).

15 BOA, C.BH, 149/7106/9-2 (27 Eylül 1699/2 Rebî‘ülâhır 1111). Bu hükmün, birebir aynı ifadelerle kayda geçmiş farklı bir kopyası için bkz. Cumhurbaşkanlığı Devlet Arşivleri Başkanlığı Osmanlı Arşivi (BOA), Maliyeden Müdevver Defteri (Bundan sonra MAD), 9885, s.131. Bu belge 2 Ekim 1699/7 Rebî'ülâhır 1111 tarihiyle kaydedilmiştir. Bu hükümlerin dışında 2 Mart 1700/11 Ramazan 1111 tarihinde Adana Beylerbeyi Mehmed'e bir başka hüküm daha gönderilerek, gemi inşası için istenen demire ilave olarak, Abdurrahman Ağa'nın talebi doğrultusunda demir sevk etmesi emredilmişti. BOA, MAD, 9885, s.204. Bu hükmün bir başka kopyası Abdurrahman Ağa'ya 3 Mart 1700/12 Ramazan 1111 tarihinde gönderilmişti. Bkz. BOA, MAD, 9885, s. 204. Abdurrahman Ağa'ya gönderilen bu hükmün aynı ifadelerle bir başka kopyası için ayrıca bkz. Cumhurbaşkanlığı Devlet Arşivleri Başkanlığı Osmanlı Arşivi (BOA), İbnülemin Bahriye (Bundan sonra İE.BH), 10/914. 
yükletip nakletmeleriydi. Bu çerçevede gerek satın alma bedellerinin, gerekse nakliye ücretlerinin Abdurrahman Ağa tarafından ödeneceği zikredilmişti ${ }^{16}$. Ayrıca inşa organizasyonu esnasında lazım olan mühimmat biraz daha detaylandırılmıştı. Buna göre, gemilerin imalatı için kirpâs, zift, katran, üstüpü, kevçi (keneviçe), kova, boya, keçe, lenger, varil, çeşitli ebatlarda kazanlar, çeşitli ebatlarda makara, yağ, kurşun, çeşitli aletler, tüfek ve toplar için barut ve fitil, fener, gibi malzemeler ve peksimed, buğday gibi yiyeceklerin gerekli olduğu belirlenmişti. Bu mühimmatın temini için Birecik'e yakın yerlerin tercih edilmesi ayrıca vurgulanmışt ${ }^{17}$. Malzeme tedarikinin planlanması sürecinden anlaşılacağı üzere, gemi yapımı için gerek nazır tayininde, gerekse levazım tedarikinde Rakka, Halep, Maraş, Ayıntab, Diyarbakır, Malatya gibi Birecik'e yakın yerler tercih edilmişti. Özellikle nakliyesi zor olan kerestenin temini için tercih edilen yerler suyolunun da kullanılabileceği, kesimlik ağaçların olduğu bölgelerdi. Gerekli olan diğer mühimmat ise nakliye masraflarını ve zamanını mümkün mertebe azaltacak bölgelerden temin edilmeye çalışılmıştı. Nitekim gemi inşa organizasyonunda ön plana çıkan bu durum, Osmanlı Devleti'nin sefer organizasyonlarında da üzerinde durduğu temel öğelerden biriydi.

Gemi yapım işinin planlandığı ve bu doğrultuda yazışmaların yapıldığı esnada, gemilerin teçhizi konusu da gündemdeydi. Bu kapsamda Rakka valisine gönderilen bir hükümde, önceki Rakka valisi Vezir Yusuf Paşa'nın döktürmekle yükümlü olduğu toplar ile ilgili bilgi istenmişti. Nitekim Yusuf Paşa'nın döktürdüğü toplara dair bir malumatın bulunmadığı dile getirilmiş ve Rakka valisinden bu topların hangi ebatta, hangi kalibrede gülleler atabildiği, nerelere konumlandırıldığı bilgisinin Abdurrahman Ağa'ya bildirilmesi istenmişti ${ }^{18}$. Anlaşılacağı üzere bu toplardan uygun olanlarının gemilerin teçhizinde kullanılması planlanmıştı.

Gemi inşa organizasyonu çerçevesinde mühimmat temininin yanında, nitelikli eleman ve işgücünün temini de planlanıyordu. Nitekim bu işin organizasyonunda önemli görev alacak yahut planlayacak usta ve nitelikli elemanlar İstanbul'dan gönderilmişti.

BOA, C.BH, 149/7106/9-2 (27 Eylül 1699/2 Rebî‘ülâhır 1111). Bu belgenin 2 Ekim 1699/7 Rebî‘ülâhır 1111 tarihli farklı bir kopyası için bkz. MAD, 9885, s.131. BOA, C.BH, 149/7106/3 (7 Ekim 1699/12 Rebîuülâhır 1111). 1699/4 Rebî‘ülâhır 1111 tarihli farklı bir kopyası için bkz. BOA, MAD, 9885, s.128. 
Tablo 1: Gemi Yapımını Organize Etmek İçin İstanbul'dan Gönderilen Görevliler

\begin{tabular}{|c|c|c|c|}
\hline Adı & Mesleği & $\begin{array}{c}\text { Harcirah } \\
\text { (Kuruş) }\end{array}$ & $\begin{array}{c}\text { Yevmiye } \\
\text { (Akçe) }\end{array}$ \\
\hline Murad & Kaptan & 400 & - \\
\hline Sakızlı Uzun Yanaki & $\begin{array}{c}\text { Marangoz } \\
\text { (Mimarbaşı) }\end{array}$ & 70 & 60 \\
\hline Baba Yusuf & $\begin{array}{c}\text { Marangoz } \\
\text { (Dağ mimarı) }\end{array}$ & 70 & 60 \\
\hline Kasımpaşalı Usta Ali & Demirci & 90 & - \\
\hline Tersaneli Usta Kadri & Demirci & 90 & 50 \\
\hline Tophaneli Hasan & Kürek yapıcı & 60 & 50 \\
\hline - & Kalafatçı & 60 & 50 \\
\hline - & Burgucu & 60 & - \\
\hline - & Araba yapıcı & 60 & \\
\hline
\end{tabular}

Kaynak: BOA, C.BH, 149/7106/5 19

Tablodan da anlaşıldığı üzere Birecik’te yapılması planlanan gemiler için İstanbul'dan 9 kişi görevlendirilmişti. Bunlardan ilki bir hizmetkârıyla birlikte Donanma Kethüdalığına atanan Murad Kaptan'dı. İstanbul'dan gönderilen elemanlar içerisinde gemilerin tekmil işinin kontrolü ve danışma merci görevinin yürütücüsü olarak en yüksek ücreti Murad Kaptan almıştı. Murad Kaptan’a Birecik’e ulaşması için verilen harcırah 400 kuruştu. Gemi yapımında diğger marangozları yönlendirecek usta, Sakızlı Uzun Yanaki adında bir marangozdu. 70 kuruş harcırah ve 60 akçe yevmiyeyle gönderilen Yanaki mimarbaşı olarak görevlendirilmişti. Planlanan gemiler için uygun kereste kesimini ise bir başka marangoz Baba Yusuf organize edecekti. Dağ mimarı olarak atanan Yusuf'a tayin edilen harcırah ve yevmiye mimarbaşı olan Yanaki ile aynıydı. Gemi inşası için temel mühimmat olan kerestenin temininde ve kullanılmasında bu iki tecrübeli usta atandı̆̆ı gibi,

19 Tahir Sevinç tarafindan da aynı kaynak kullanılarak bir tablo oluşturulmuştur. Lakin tabloda esası bozacak okuma ve değerlendirme hataları yapılmıştır. Bunlardan ilki, Sevinç tarafindan oluşturulan tabloda sadece harcırah bilgilerine yer verilmiş, ancak bu bilgilerin bir kısmı yevmiye bilgileriyle karıştırılarak hatalı şekilde tabloya yansıtılmıştır. Bunun dışında kafa karışıklığına ve hatalı değerlendirmelere neden olabilecek bir okuma hatası yapılmıştır. Metinde "Murad Kapûdân bir nefer Hidmedkârıyla" şeklinde geçen kelimeler "Marangoz (görevi), Hüdavendigarlı (ismi)" şeklinde okunmuştur. Bkz. Sevinç, a.g.m., s. 61. 
demir işlenmesinde de yine iki usta gönderilmişti. Nitekim Kasımpaşalı Ali Usta ile Tersaneli Kadri Usta 90 kuruş harcırahla Birecik'e tayin edilmişti. Bu görevlilerin dısında, yine gemi yapımında yer alacak birer kürek yapıcı, kalafatçı, burgucu ve araba yapıcı ustası sevk edilmişti. Bu ustalara da 50 ila 60 kuruş arasında değişen harcırahlar tayin edilmişti. Toplamda İstanbul'dan sevk edilen görevlilere 960 kuruş harcırah verilmişti ${ }^{20}$. Anlaşlacağı üzere İstanbul'dan Birecik'e tayin edilen bu görevliler Abdurrahman Ağa'nın yanında, yapılacak olan firkatelerin temel organizasyonun planlanmasında görev almıştı. Daha önce bu ölçekteki gemilerin Birecik'te inşa edilmemiş olmasından, yapım işini organize edip, inşa işinde görevlendirilen diğer usta ve çalışanları yönlendirecek ustalar İstanbul'dan sevk edilmişti.

Gemi yapımını organize edecek İstanbul'dan gönderilen bu görevliler dışında, bölgeye yakın olan yerlerden de gemi inşa işinde çalışacak usta ve işçiler istenmişti. Buna göre Trablusşam, Beyrut ve Sayda gibi Birecik'e yakın yerlerden marangoz, kalafatçı, kürekçi gibi ustalar ve işgücünü sağlayacak ameleler talep edilmişti. Bu yerler dışında dikkati çeken ve kısmen Birecik'e uzak kalan bölge Kıbrıs'tı. Nitekim aynı tarihte Kıbrıs beylerbeyinden de usta ve amele temin edip göndermesi emredilmişti ${ }^{21}$. Gemi yapım organizasyonunun planlandığı süreçte insan gücü talebi sadece, inşa işinde çalışacak personelle sınırlı değildi. Bunun yanında gemiler tamamlandıktan sonra cenkçi ve kürekçi olarak görev yapacak personel teminiyle ilgili planlama da yapılmaya çalışılmıştı. Bu çerçevede Rakka valisine gönderilen emir kayda değer bilgiler vermekteydi. Belgede Rakka valisinden gemiler için gerekli kürekçi ve cenkçi ihtiyacını Ruha, Birecik, Maraş, Ayıntab, Halep, Rumkale'deki aşiretlerden temin edip göndermesi istenmişti. Ayrıca Rakka valisinin, "harbe ve cenge" kadir insan gücünü sağlarken Abdurrahman Ağa'yla da gemilerin ihtiyacı çerçevesinde irtibat halinde olması gerektiği belirtilmişti2 ${ }^{22}$.

Gemi yapım organizasyonuna dair ilk atamaların yapılması ve nazır tayin edilen Abdurrahman'a yardım edecek personelin görevlendirilmesinden sonra, ilk yapı-

20 BOA, C.BH, 149/7106/5 (10 Ekim 1699/15 Rebî‘ülâhır 1111).

21 BOA, C.BH, 149/7106/4 (10 Ekim 1699/15 Rebî‘ülâhır 1111). Bu belgenin farklı bir kopyası için bkz. BOA, MAD, 9885, s.177-178; Sevinç, a.g.m., s. 60. Bununla beraber, çalışmanın ilerleyen safhasında ifade edildiği üzere, incelenen muhasebe defterlerindeki veriler Kıbrıs’an bir iş gücünün gelmediğini göstermektedir.

22 BOA, C.BH, 149/7106/2 (27 Eylül 1699/2 Rebî‘ülâhır 1111). Bu belgenin 29 Eylül 1699/4 Rebî‘ülâhır 1111 tarihli farklı bir kopyası için bkz. BOA, MAD, 9885, s.129-130; Sevinç, a.g.m., s. 60 . 
lan icraatlardan birisi gemilerin yapım yerinin tespiti ve inşa için temin edilecek malzemenin saklanacağı mahallin belirlenmesiydi. Bu doğrultuda Abdurrahman Ağa'nın isteği doğrultusunda yazılan bir arz oldukça aydınlatıcı veriler sunmaktadır. Nitekim arzda Abdurrahman Ağa’nın talebi doğrultusunda, gemilerin yap1lacağı ve gemi yapımı için toplanan mühimmatın saklanacağı bir yer gösterilmesi Birecik'in yöneticilerinden istenmişti. Bu çerçevede şehrin "ulemâ ve sulehâ ve sâdât-1 kirâm ve sâir a 'yânı" bir mecliste toplanarak bu iş için uygun yeri tespit etmişti. Buna göre gemi yapımı için uygun yer, Birecik'in güney tarafinda hisarın başkulesi olan "Ala kule" olarak belirlenmişti. Tespit edilen bu yerin uygun olup olmadığı merkezden gönderilen Murad Kaptan’a ve tecrübeli marangozlara da danışılmış, onların da onayı alınmıştı ${ }^{23}$. Bahsedilen bu yer tespit işi, Abdurrahman Ağa ve İstanbul'dan gönderilen Murad Kaptan ve tecrübeli ustaların ilk icraatlarindandi.

Abdurrahman Ağa ve İstanbul'dan gönderilen ekibin gemi inşaat alanının belirlenmesinin yanında eş zamanlı olarak yaptıkları bir diğer icraat, gemilerin hangi ölçüde ve özelliklerde inşa edileceği mevzuydu. Abdurrahman Ağa'nın Birecik’te inşa edeceği gemi adedi 98 adetti ${ }^{24}$. Ancak yukarıda da vurgulandığı gibi bunların 60 tanesi firkate nevinden, daha önce bölgede kullanılmamış büyük çaplı gemilerdendi. Öyle ki bu 60 geminin 20 adedi diğerlerinden büyük yapılması planlanmıştı. Ne var ki gemilerin hangi ölçekte ve ebatlarda yapılacağı, suyolunun kapasitesiyle sınırlıydı. Ve bu sınırların belirlenmesi adına yaklaşık iki ay önce (27 Eylül 1699/2 Rebî‘ülâhır 1111 tarihinde) Rakka beylerbeyine ve Birecik kadısına bir hüküm gönderilmişti ${ }^{25}$. Nitekim hükmün gönderilmesinden yaklaşık bir buçuk ay sonra (11 Kasım 1699/18 Cemâziyelevvel 111 'de), kayda geçen başka bir belgede gerekli tahkikatın yapıldığı ve inşa edilecek büyük çaplı gemilerin ebatlarıyla ilgili tespitlerin ortaya konulduğu görülmektedir. Buna göre inceleme Birecik’ten Basra’ya nehirden taşımacılık yapan kişiler vasıtasıyla yapılmıştı. Bu çerçevede

BOA, C.BH, 90/4305/2 (11 Kasım 1699/18 Cemâziyelevvel 1111).

24 Abdurrahman Ağa, kendi mübaşeretinde kaydı tutulan gemilerin yapımıyla ilgili muhasebe defterlerinde, 60 adet firkate, 25 adet filika ve sandal, 5 adet piyade kayığı ve 8 adet "tuna açuğu" (üstüaçık) olmak üzere toplam 98 adet gemi yapımını üstlenmişti. BOA, MAD, 5433, s. 2. Illgili kaynağın önceki kullanımı için bkz. Orhonlu-Işıksal, a.g.m., ss. 85-86, 99. Aynı kaynak Tahir Öğüt tarafindan da kullanılmış ancak Abdurrahman Ağa'nın yaptığı gemi adedi 38 olarak kaydedilmiştir. Bkz. Öğüt, a.g.e., s. 250, 252. Tahir Sevinç ise gemilerin sayılarını doğru vermiş, fakat -muhtemelen sehven- firkatelerin uzunluğunu 4,5 zira, genişliğini 21-27 zira göstermiştir. Bkz. Sevinç, a.g.m., s. 60.

BOA, C.BH, 149/7106/9-1. 
gemilerin hareket edeceği güzergâhta, bölgede işinin ustası dümenci, kürekçi gibi nehir taşımacılığında deneyimli kişiler bir zahire gemisiyle/sandalıyla Şattü'l-Arab’a kadar gidip tespitlerde bulunmuşlardı. Debinin düşük olduğu sonbahar aylarında yapılan bu tespitlere göre, Deyr ile Ane ve Ane ile Hayt arasındaki suyolları oldukça sıkıntıydı. Bu bölgeler arasındaki gemilerin geçişi için inşa edilmiş olan bentler oldukça eski, bakımsız ve dardı. Ayrıca bentlerin içerisinde geçişi zorlaştıracak "döküntü taşlar" bulunmaktaydı ve suyun debisinin az olduğu zamanlarda geçişlerde sıkıntılar yaşanabiliyordu. Özellikle sıkıntının yaşanabileceği noktalar, bentlerin arasında geçişlerin sağlandığı kapı olarak tarif edilen geçişin iyice daraldığı alanlardı. Bu alanlarda nehrin debisinin azaldığı zamanlarda, suyolunun uzunluğu 6 "neccari zira"26ya (4,5 metre), derinliği ise 1 "neccari zira"ya $(0,75$ metre) kadar düşüyordu. Fellüce'ye kadarki suyolunun vaziyeti bu şekildeydi. Fellüce'den Şattü'l-Arab'a kadar var olan güzergâhta ise gemilerin seyretmesi için bir sıkıntı yoktu. Ne var ki gemilerin yapım süreciyle ilgili hükmün ortaya koydukları sadece yapılan tahkikatın sonuçlarıyla sınırlı değildi. Bu tahkikat gemi yapımını yürütecek ustalar ve gemilerin Firat'ta seyrini sağlayacak kaptanlar tarafindan değerlendirilmiş ve bu kişiler tarafindan gemilerin ne şekilde inşa edileceğine dair bir sonuca ulaşılmıştı. Buna göre değerlendirmeyi yapacak uzmanlar arasında gemilerin inşa işine memur edilmiş, sabık Tuna kethüdası Murad Kaptan, onun misafiri Osman Kaptan, İbrahim ve Mahmut kaptanlar bulunmaktaydı. Ayrica kaptanların yanında gemi inşasının teknik kısımlarıyla ilgili kararları verecek mimarbaşı Sakızlı Uzun Yanaki ve Dağ mimarı Yusuf Bey yer almıştı. İlgili uzmanlar elde edilen bilgileri değerlendirdikten sonra inşa edilecek firkatelerin Firat'ta seyredebilmesi için maksimum büyüklügünün 27 neccari zira uzunluğunda, 4,5 neccari zira genişliğinde (20,5 metre uzunluk- 3,4 metre genişliğinde) ve 16 oturaklı olması gerektiğine kanaat getirmişlerdi. Ayrıca gemilere yüklenecek personel ve teçhizatın da sınırlarını belirlemişlerdi. Buna göre gemilere kürekçisi, topçusu, cenkçisiyle beraber en fazla 70 adam ve 7 kita top teçhiz edilmeliydi. Bu hesaba göre gemilere konulacak topların büyüklüğü de önemliydi. Öyle ki topların ancak 2 tanesi ağızdan dolma 20 vukiyye atar büyük kalibreli ağır top olabilirdi. Diğger 1 tanesi 1,5 vukiyye atar koğuş topu, kalan 4 adedi ise saçma adı verilen küçük ka-

26 Neccari, mimari ya da inşaat arşımı olarak bilinen uzunluk birimi. Bu uzunluk biriminin metrik karşlığı 75,8 cm olarak hesaplanmıştır. Walter Hınz, Íslam'da Ölçü Sistemleri, Çev. Acar Sevim, Marmara Üniversitesi Yay., İstanbul 1990, s. 73; Mehmet Erkal "Arşın”, DİA, C. III, TDV. Yay., İstanbul 1991, s. 412. 
libreli toplardan teşekkül edilmeliydi ${ }^{27}$. Yapılan bu hesaplamalarda değişmeyecek temel veri, firkatelerin maksimum ebatlarıydı. Ne var ki, özellikle gemilere yerleştirilecek topların kalibreleri dolayısıyla ağırlıkları, yine ağırlığı etkileyecek olan gülle ve barut miktarı gemilerdeki personel ve teçhizatın dağılımını değiştirebilirdi. Ancak firkatelerin hiçbiri 27 zira (20,5 metre) uzunluğu ve 4,5 zira (3,4 metre) genişliğinin üzerinde inşa edilmemiş, yani gemi yapım sürecinde suyolunun özellikleri çerçevesinde yapılan tahkikata sonuna kadar sadık kalınmıştı $1^{28}$.

\section{Mali Kayıtlar Üzerinden Bir İnceleme: Gemilerin İnşası}

Birecik'te yapımı planlanan gemiler için, inşa öncesi kalifiyeli iş gücü temin edilmiş, temel malzemelerin tedarikine başlanmış, inşaat alanı tespit edilmiş ve en önemlisi büyük gemilerin (firkatelerin) hangi ebatlarda inşa edileceği belirlenmişti. Bu temel hazırlıkların tamamlanmasının akabinde Abdurrahman Ağa idaresinde gemi yapım işine başlanmıştı. İfade edildiği üzere toplamda 98 adet geminin yapımı için Abdurrahman Ağa, 4 Aralık 1699 ila 30 Eylül 1700 (11 Cemâziyelâhir 1111 ila 16 Rebî́ülâhır 1112) tarihleri arasında, 300 günlük bir çalışma yürütmüştü${ }^{29}$. Bu süreçte Abdurrahman Ağa inşa işinin gelir giderini kontrol etmiş, dolaylsıyla tüm mali kayıtlar onun yaptığı harcamalar çerçevesinde tutulmuştu. Nitekim bu mali kayıtlar inşa sürecinin ayrıntılarını ortaya koymaktadır.

Mali açıdan ele alındığında, gemi yapım sürecine başlanmadan evvel Abdurrahman Ağa'nın en temel sorunu bu iş için gerekli finansal kaynağı sağlamaktı yahut nakit parayı temin etmekti. Öyle ki, askerî harcamalarla ilgili pek çok konuda olduğu gibi, Birecik'teki büyük ebatlı gemi yapım sürecinde de finansman, bölgesel kaynaklar kullanılarak sağlanmaya çalışılmıştı.

BOA, C.BH, 90/4305/5 (11 Kasım 1699/18 Cemâziyelevvel 1111).

İnşa edilen firkatelerin 21 adedi 27 zira boy ve 4,5 zira (20,5 metre uzunluk- 3,4 metre) genişliğinde, 10 adedi 26 zira boy ve 4,5 zira (19,7 metre uzunluk- 3,4 metre) genişliğinde, 9 adedi 25 zira boy ve 4,5 zira (18,9 metre uzunluk- 3,4 metre) genişliğinde, 10 adedi 23,5 boy ve 4,5 zira (17,8 metre uzunluk- 3,4 metre) genişliğinde ve son 10 adedi 21 zira boy ve 4,5 zira (15,9 metre uzunluk- 3,4 metre) genişliğindeydi. Bkz. BOA, MAD, 5433, s. 2. Anlaşılacağı üzere teçhizat ve personelin sayısı gemilerin kapasitesine göre de değişim gösterebilmekteydi.

29 BOA, MAD, 5433, s. 2. 
Tablo 2: Birecik’te İnşa Edilen Gemiler İçin Tahsis Edilen Temel Finansal Kaynaklar

\begin{tabular}{|c|c|c|c|}
\hline Finans Kaynağının Adı & Miktarı/Kuruş & Oranı & Tarih \\
\hline Halep hazinesi & 5.000 & $\% 4,5$ & 21 Rebî‘ülâhır 1111 \\
\hline Halep hazinesi & 15.000 & $\% 13,5$ & 16 Receb 1111 \\
\hline Halep hazinesi & 25.000 & $\% 22,5$ & 22 Safer 1112 \\
\hline Halep hazinesi & 7.500 & $\% 6,7$ & 21 Rebî‘ülâhır 1111 \\
\hline Trablusşam mukataası & 7.000 & $\% 6,3$ & 16 Receb $1111^{30}$ \\
\hline Maraş bedeli & 30.000 & $\% 27$ & - \\
\hline Halep mahsulatı & 8.333 & $\% 7,5$ & - \\
\hline $\begin{array}{l}\text { Ayas ve Payas neferatının } \\
\text { mevacibi } \\
\text { (Adana mukataası malından) }\end{array}$ & $1.300,5$ & $\% 1,2$ & - \\
\hline $\begin{array}{l}\text { Maraş kalesi neferatı } \\
\text { mevacibi } \\
\text { (Ayıntab dimosu malından) }\end{array}$ & 413 & $\% 0,4$ & 24 Safer 1112 \\
\hline $\begin{array}{l}\text { Halep neferatının mevacibi } \\
\text { (Halep'teki ocaklıklardan) }\end{array}$ & 7.644 & $\% 6,9$ & - \\
\hline $\begin{array}{l}\text { Trablusşam neferatının } \\
\text { mevacibi } \\
\text { (Halep mahsulatından) }\end{array}$ & 914 & $\% 0,8$ & - \\
\hline Rakka eyaleti mukataası & 3.129 & $\% 2,8$ & - \\
\hline Toplam & \multicolumn{3}{|l|}{$111.233,5$} \\
\hline
\end{tabular}

Kaynak: BOA, MAD 5433, s.2; BOA, D.BŞM 964 s. 2.

Abdurrahman Ăga'ya gemi yapım sürecinde tahsis edilen miktar 121.383,5 (14.566.020 akçe) esedi kuruştu. Ancak bu miktar içerisinden merkezden gönderilen 10.150 esedi kuruş, "Şat kapûdânı" olarak atanan Mehmed Paşa'ya verilmişti. Her ne kadar bu para Abdurrahman Ağa’nın gelirleri arasında görünse de Abdurrahman Ağa bu parayı hiç almamış ve gemi yapımı için kullanmamıştı. Bu nedenden dolayı Abdurrahman Ağa için tahsis edilen rakam gerçekte 111.233,5

30 İlgili miktarın Abdurrahman Ağa'ya teslim edildiğine dair bir başka kayıt için bkz. BOA, IEE.BH, $10 / 913$. 
esedi kuruşluk gelirden müteşekkildi ${ }^{31}$. Buradan hareketle tablodaki verileri değerlendirecek olursak, Abdurrahman Ağg'ya gemi inşa sürecinde tahsis edilen gelirler, başta Halep, Maraş, Trablusşam, Rakka, Ayıntab hazinelerinden sevk edilmiş, çevredeki eyalet gelirlerinden oluşmaktaydı. Bu miktar içerisine \%62,4’lük miktarla en önemli gelir Halep hazinesinden aktarılmıştı. Yine kayıtlardan anlaşıldığı kadarıyla Abdurrahman Ağa henüz gemi inşa faaliyetlerine başlamadan önce tahsis edilen gelirin en az \% 1 l'lik kısmı eline ulaşmıştı. Tüm bunların yanında gemi yapım işinin yürütüldüğü 300 günlük süreçte 111.233,5 esedi kuruşluk miktarın tamamının tahsili geçekleşmemişti. Abdurrahman Ağa'ya 18.863,5 esedi kuruşluk meblă̆, yani tahsis edilen miktarın \%17’lik kısmı, tahsil edilip gönderilememişti. Kendisine ulaştırılamayan bu miktarın en büyük kısmı 9.410 esedi kuruş ile Maraş bedeliyesinden tahsil edilip gönderilemeyendi. Bir diğer baki kalan miktar Halep’te görev yapan bir kısım askerin Halep ocaklıklarına ait meblağından havale edilmesi istenen tutardı. Buna göre 7.644 esedi kuruşun 5.410'luk kısmı toplanıp gönderilememişti. Yine aslen Trablusşam'da görev yapan askerlere tahsis edilen 914 esedi kuruşluk gelir, Abdurrahman Ağa'ya ulaştırılamayan meblağdandı. Son olarak Rakka mukataasından tahsis edilen 3.129 esedi kuruşluk miktar Abdurrahman Ağa'nın eline ulaşmamıştı. Anlaşılacağı üzere Abdurrahman Ağa'nın gemi yapım sürecinde kullanabileceği miktar 92.370 esedî kuruştan müteşekkildi² .

İncelenen mali kayıtlar dahilinde, Abdurrahman Ağa’nın gemi yapım sürecinde harcama kaleminin başında "el-mübayat" başlı̆̆ı altında satın alımlar yer almıştı. Burada gerçekleşmişs satın alımlar 4 Aralık 1699-30 Eylül 1700 (11 Cemâziyelâhir 1111 ila 16 Rebî‘ülâhır 1112) tarihleri arasında, Abdurrahman Ağa’ya tahsis edilmiş gelirler çerçevesinde ve elindeki bir miktar nakitle yapılmıştı. Bu doğrultuda özellikle büyük ölçekli nehir gemilerinin inşası için gereken çeşitli ebatlarda ve

31 Tahir Sevinç de Abdurrahman Ağa'nın gemi inşa sürecinin finansmanıyla ilgili birtakım bilgiler vermiştir. Ancak verdiği bu bilgiler hem tutarsız hem de çok eksiktir. Buna göre ilk olarak, inşa edilecek gemilerin masrafı, işçilik ücreti ve inşasında kullanılacak malzemenin Halep cizye ve mahsulatından sağlanan 12.500 kuruşla karşılandığını ifade etmiştir. Çalışmasının başka bir yerindeyse bir tablo içerisinde, Halep mahsulatının yanında Trablusşam mukataasından da 7.500 kuruş daha sarf edildiğini aktarmış, yani toplamda 20.000 kuruşla finansmanın sağlandığını belirtmiştir. Bkz. Sevinç, a.g.m., s. 60, 66. Anlaşılacağı üzere Sevinç’in verdiği bu rakamlar Abdurrahman Ağa'ya gemi yapımı için tahsis edilen gelirleri ifade etmekten çok uzaktır. Dahası bu rakamlar gelirlerin sağlanması adına yapılan yazışmalardan alınmış verilerdir. Yani yanlış kaynaktan çıkarılmış eksik bilgilerdir.

32 BOA, MAD, 5433, s. 2; Cumhurbaşkanlığı Devlet Arşivleri Başkanlığı Osmanlı Arşivi, Bâb-1 Defteri, Başmuhasebe Defterleri (Bundan sonra D.BŞM), 964, s. 2. 
özelliklerde kumaş, urgan, ip, kereste ve diğer muhtelif mühimmatın satın alımı sağlanmıştı.

Tablo 3: Birecik’te İnşa Edilen Gemiler İçin Satın Alınan Mühimmat

\begin{tabular}{|c|c|c|c|}
\hline Satın Alınan Malzeme & $\begin{array}{c}\text { Miktarı/ } \\
\text { Kuruş }\end{array}$ & $\begin{array}{c}\text { "Mübâya'ât" } \\
\text { Harcamaları } \\
\text { İçerisindeki } \\
\text { Oranı }\end{array}$ & Satın Alındığı Yer \\
\hline Kirpâs-1 ham & $4.033,5$ & $16,2 \%$ & Maraş \\
\hline Kirpâs-1 zinharî & 573,5 & $2,3 \%$ & Halep \\
\hline $\begin{array}{l}\text { Kirpâs-1 sürh-i Diyarbekir } \\
\text { berâ-yı lâzime-i sancak }\end{array}$ & 450 & $1,8 \%$ & - \\
\hline Elvan dârâyî $^{33}$ & 239 & $1,0 \%$ & - \\
\hline İplik & 86 & $0,3 \%$ & - \\
\hline İplik-i kolan ${ }^{34}$ & 155 & $0,6 \%$ & - \\
\hline İplik-i tağat? & 93 & $0,4 \%$ & - \\
\hline Sicim-i kendir & 250 & $1,0 \%$ & - \\
\hline Çuka & 372,5 & $1,5 \%$ & \\
\hline $\begin{array}{l}\text { Kirpâs, zift, katran, şem-i } \\
\text { asel, keçe, revgan-1 pih, } \\
\text { revgan-1 zeyt, kova vs. }\end{array}$ & 1.838 & $7,4 \%$ & - \\
\hline Kazgan-1 mezbûrûn & 161 & $0,6 \%$ & Antep, Maraş \\
\hline $\begin{array}{l}\text { Resen-i kendir, palamar } \\
\text { alat-1 gomana }\end{array}$ & $7.325,5$ & $29,4 \%$ & - \\
\hline $\begin{array}{l}\text { Çeşitli boya ve mühimmat } \\
\text { ve nakkaşların ücreti }\end{array}$ & 939,5 & $3,8 \%$ & - \\
\hline $\begin{array}{l}\text { Üstüpü, revgan-1 bezir, } \\
\text { revgan-i pih, kendir, } \\
\text { palamar, zift, katran vs. }\end{array}$ & 3.443 & $13,8 \%$ & - \\
\hline Kömür & $2.556,5$ & $10,3 \%$ & - \\
\hline Muhtelif mühimmat & 82 & $0,3 \%$ & - \\
\hline
\end{tabular}

33 Renkli, sert kumaş. İsmail Parlatır, Osmanlı Türkçesi Sözlüğü, Yargı Yay., Ankara 2006, s. 319.

34 Yassı ip, salıncak ipi ya da çadır kenarına dikilen enli ve kalın ip anlamlarına gelen bir çeşit ip. Parlatır, a.g.e., s. 916. 
Abdurrahman Ağa'nın 1700 (H.1111) Tarihli Gemi İnşa Faaliyeti

\begin{tabular}{|l|l|l|l|}
\hline Ham demir ve kurşun & 553 & $2,2 \%$ & Antep, Halep \\
\hline Kerestehâ & 1.553 & $6,2 \%$ & $\begin{array}{l}\text { Antep, Antep, } \\
\text { Birecik }\end{array}$ \\
\hline Zift, mismâr, demirci küreği & 209 & $0,8 \%$ & - \\
\hline Toplam & $24.924,5^{35}$ & & \\
\hline
\end{tabular}

Kaynak: BOA, MAD, 5433 s.2-5 ; BOA, D.BŞM, 964 s. 2-3.

Tablodan anlaşıldığı üzere "mübâya'a" başlığı altında büyük çoğunluğu satın alınan malzemeye ödenen tutar 24.924,5 esedi kuruştu. Bu miktar toplam harcama tutarının \%23,38’ine, Abdurrahman A ğa'nın toplayabildiği gelirlerin ise \%27'sine karşılık gelmekteydi. "Mübâya'a" başlığı altında yapılan harcama içerisinden yaklaşık \%20’lik kısmı çeşitli cinste kirpâs alımı için kullanılmıştı. Kirpâs yahut kirbas, pamuk ipliğinden dokunan bir çeşit beze verilen addı. Bu bez genellikle gemi yelken ve tentelerinin işlenmesinde kullanılıyordu ${ }^{36}$. Nitekim Abdurrahman Ağga'nın yaptığı alımda, 60 adet firkatenin ihtiyaçları için çeşitli kirpâs tedarik edilmişti. Bu çerçevede, her bir firkate için 59 top olmak üzere toplam 3.540 top "kirpâs-1 ham", her bir firkate için 5,5 top olmak üzere 330 top "kirpâs-1 zinharî" ve yine her bir firkate için 5 top olmak kaydıyla 300 top "kirpâs-1 sürh-i Diyarbekir" Maraş, Halep ve Diyarbakır'dan satın alınmıştı ${ }^{37}$.

Abdurrahman Ağa'nın "mübâya'a" başlığı altında gerçekleştirdiği en büyük alım 7.325,5 esedî kuruş ödeyerek gerçekleştirdiği resen-i kendir, palamar ve gomana satın alımlarıydı. Bu iş için mübâya'a çerçevesinde harcanan paranın yaklaşık \%30'u kullanılmıştı. İp, urgan, halat anlamına gelen resen gemi yapımında kullanılan temel malzemelerden biriydi38. Anlaşılacağı üzere "resen-i kendir", kendirden üretilen bir tür halattı ve 60 adet firkatenin ihtiyaçları mukabilinde satın alınmıştı. Kayıttaki ayrıntıya göre her bir firkate için yaklaşık 4,25 kantar (239,7 kg) ${ }^{39}$ resen-i kendir satın alınmıştı. Alınan resen-i kendir başta çarmıh adlı halat yapımı olmak üzere birtakım mühimmatın temini için kullanılmıştı. 60 adet firkate için kullanılan bir diğger büyük halat ise palamardı. Palamar, gemileri karaya bă̆-

35 Bu rakam kaynaklardaki toplam rakamdır. Tablodaki rakamların toplamı 24.913 esedi kuruştur. Yani bu başlık altında masraflar 11,5 kuruş fazla gösterilmiş yahut işlem hatası yapılmıştır.

36 Bostan, a.g.e., s. 154.

37 BOA, MAD, 5433, s. 2-3; BOA, D.BŞM, 964, s. 2.

38 Bostan, a.g.e., s. 142.

39 Cengiz Kallek, “Kantar”, DİA, C. 24, TDV. Yay., İstanbul 2001, s. 319. 
lamak veya zincir yerine lengere tutturmak için kullanılan halata verilen isimdi ${ }^{40}$. Her bir firkate için 2 parça, toplamda yaklaşık 172 kantar $(9.701 \mathrm{~kg})$ ağırlı̆̆ında palamar satın alınmıştı. Firkateler için temin edilen önemli halatlardan bir diğeri gomanaydı. Kadırga tarzında daha büyük gemiler için her kadırgaya 5 adet gomana tedarik edilirken ${ }^{41}$, Birecik'te inşa edilen firkatelerin her birine 3 adet gomana satın alınmışt1 ${ }^{42}$.

"Mübâya'a" başlı̆̆ı altında dikkati çeken bir diğer alım Abdurrahman Ağa ve ekibi tarafından "bahâ-i mezbûrûn" başlığı altında gemi inşası için gerekli muhtelif mühimmatın temini adına yapılmıştı. Bu satın alımlar içerisinde özellikle dikkati çeken, 3.443 esedî kuruş ödenerek gemilerin kalafatı ${ }^{43}$ için gerekli malzemenin temin edildiği alımdı. Nitekim ilgili rakam içerisinden kalafat için 123,5 kantar $(6.937 \mathrm{~kg})$ üstüpü ${ }^{44}, 613,75 \mathrm{kantar}(34.615 \mathrm{~kg})$ zift, $163 \mathrm{kantar}(9.193 \mathrm{~kg})$ koyun postu (post-1 ganem) ve 30 kantar (1.692 kg) katran 2.717 kuruş ödenerek satın alınmıştı. Ayrıca, 3.443 kuruşluk harcamadan geriye kalan 726 kuruşla revgan-ı bezir, revgan-1 pih (don yağı), kendir, palamar ve manivela tedarik edilmiști ${ }^{45}$. "Bahâ-i mezbûrûn" başlı̆̆ı altında dikkat çeken bir diğer harcama yine gemi inşası için gerekli muhtelif mühimmatın 1.838 esedi kuruş harcanarak sağlandığı alımdı $^{46}$. İlgili başlık altında yapılan harcamaların yaklaşık \% 7,5'ine karşılık gelen bu alımda, kirpâs, zift, katran, üstüpü, şem-i asel (bal mumu), keçe, revgan-1 pih, revgan-ı zeyt, döşeme-i bayburd, kova (nâm-ı diğer külek ${ }^{47}$ ) adı altında çok çeşitli mühimmat tedarik edilmişti ${ }^{48}$.

40 Parlatır, a.g.e., s. 1334.

41 Bostan, a.g.e., s. 142.

42 BOA, MAD, 5433, s. 4; BOA, D.BŞM, 964, s. 3.

43 Kalafat gemi ve kayıkların tahtalarının arasını üstüpü gibi malzemeyle tıkayı üstüne zift ve macun sürmek işine verilen ad. Parlatır, a.g.e., s. 823.

44 Keten, kenevir veya bozuk halat parçalarından elde edilen, kayık ve gemi teknelerinin aralıklarını su geçirmemesi için kullanılan bir tür malzeme. Bostan, a.g.e., s. 146.

45 BOA, MAD, 5433, s. 4; BOA, D.BŞM, 964, s. 3.

46 Tahir Sevinç, 1.838 kuruş harcanarak toplam harcama tutarının \%7,4'e tekabül eden bu harcama başlığını ayrı bir tablo haline getirmiş ve "inşa edilen gemilere temin edilen malzeme miktarı" şeklinde ifade etmiştir. Bkz. Sevinç, a.g.m., s.65. Anlaşılacağı üzere Sevinç, muhasebe kayıtları içerisinden sondajlama yaparak bütünün küçük bir parçasını almış ve bütünü açıklamak için kullanmıştır. Lakin bunu yaparken dahi ilgili başlık altındaki tüm kalemleri okumamıs, tabloya koyduğu bazı kalemlerde de -tunç dibek, demir gibi- okuma hataları yapmıştır. Kısacası Sevinç'in çalışmasında ortaya koyduğu bu veriler, Abdurrahman Ağa'nın gemi yapım sürecinin ilgili kısmını açıklamaktan çok uzaktır.

47 Bir tür tahta saplı kapa verilen ad. Parlatır, a.g.e., s. 947.

48 BOA, MAD, 5433, s. 3; BOA, D.BŞM, 964, s. 2. 
Abdurrahman Ağa ve ekibinin gerçekleştirdiği mübayaalardan bir diğeri, 2.556,5 esedî kuruş ödeyerek demir karhanesi için yaptı̆̆ı alımlardı. Satın alımlar içerisinde toplam harcanan tutarın \%10,3'lük kısmını oluşturan bu satın alımlarda, demir karhanesi için 1.248 Halep kantarı $\left(400.233,6\right.$ kg) ${ }^{49}$ kömür tedarik edilmişti. Daha önce ifade edildiği üzere gemi yapımı için demirin herhangi bir ücret ödemeden Adana gelirleri kullanılarak Adana'dan talep edilmişti. Ancak yaşanan bazı aksaklıklar sonucu Adana'dan bir miktar demir gelmemişti ${ }^{50}$. Bunun üzerine demir karhanesinde kullanılmak için eksik olan başta demir ve kurşun Halep ve Antep'ten 553 esedi kuruş harcanarak satın alınmıştı. Öyle ki satın alınan bu mühimmat 21 Halep kantarı $(6.734,7 \mathrm{~kg}$ ) demir çubuktan (timur-1 çubuk), 9 Halep kantarı (2.886,3 kg) demir cevherinden (timur-1 agûş) ve 30 kıyye $(38,4$ kg) kurşundan ibaretti. Bu mühimmatın tedariği esnasında ifade edilmesi gereken bir diğer husus, harcanan 553 esedi kuruşun tamamının demir ve kurşun için olmadığıydı. Nitekim bu tutarın 26 kuruşu ham malzemenin nakli için harcanmışt1 ${ }^{51}$.

Tabloda özet olarak ifade edilen ancak biraz daha açıklanması gereken bir diğer mübâya'a, kereste alımı çerçevesinde vuku bulmuştu. Tabloda görüldüğü üzere 1.553 kuruş ödenerek katran (tennüb, zennüb ya da karaçam olarak bilinen ağaç), karaağaç, ceviz, tut, kavak cinsinden kereste satın alınmıştı. Bu keresteler gemi inşaatında özel bir amaç için tedarik edilmişti. Öyle ki bu ağaçlar kullanılarak gemilerin kamaraları ve bölmeleri inşa edilecekti. Buna göre Antep’ten 1.200 parça katran ağacı, yine Antep’ten 28 parça karaağaç, Birecik’ten 4 parça ceviz, tut ve 10 adet kavak ağacı kerestesi alınmıştı. Bunun dışında çeşitli ebatlarda, özelliklerde ve renklerde kumaş ve iplik 1.195,5 esedi kuruş ödenerek sağlanmıştı. Mesela sancak, bayrak ve flandra yapımı için "elvan dârâyî” adı altında 239 esedi kuruş ödenerek çeşitli renkte dayanıklı kumaş tedarik edilmişti. Yine muhtelif kullanım için her bir firkateye 2,15 kıyye (2,75 kg) olmak üzere 130 kıyye $(167 \mathrm{~kg})$ iplik, fir-

19. yüzyılın başlarında odun ve kömür ölçümünde kullanılan Halep kantarının karşılı̆̆ı 320,725 kg'a karşılık gelmekteydi. Kallek, a.g.m., s. 318.

50 Öyle ki 25 Mart 1700/4 Şevval 1111 tarihli bir hükümde, Adana'dan zikredilen tarihe kadar sadece 200 kantar $(11.280 \mathrm{~kg})$ demir gönderildiği belirtilmiş ve talep edilen ancak gelmeyen demirin gönderilmesi emredilmişti. Anlaşlan Adana Beylerbeyi gemi yapım sürecinde demir talebinin tamamını karşılayamamıştı. BOA, MAD, 9885, s. 240.

51 BOA, MAD, 5433, s. 4; BOA, D.BŞM, 964, s. 3. Tahir Öğüt çalışmasında bahsedilen demirin satın alındığı yeri Adana olarak belirtmiştir. Ayrıca Öğüt, demir çubukların kantarı 21, kurşun levhaların kantarı ise 28'er kuruşa mal olduğunu ifade etmiştir. Bkz. Öğüt, a.g.e., s. 267. Ancak -dipnotun başında ifade edilmiş- kaynaklardan görüldüğü kadarıyla, demir çubuklarının kantarı 18, demir cevherinin kantarı 28, kurşunun ise 30 kıyyesinin 9 kuruşa mal edilmişti. 
katelerdeki tenteler için 200 kıyye $(256,4$ kg) "iplik-i kolat", muhtelif amaçlar için her firkateye 35 adet olmak üzere 2.100 adet kendir temin edilmişti ${ }^{52}$.

Gemi yapım sürecinde Abdurrahman Ağa'nın "el-mübâya'ât" başlı̆ğ altında yürüttüğü satın alımları gösteren kayıtlar dışında, bir diğer önemli harcamaların kaydedildiği kısım "el-ücûrât ve'l-ihrâcât" başlığıydı. Nitekim bu başlık altında başta gemi inşa işinde ve malzeme tedarik işinde çalışan neccar, marangoz, bıçkıcı, demirci, kalafatçı, hamal gibi usta ve işçiler ile gemi yapım işini yürüten mübaşir ve kâtiplerin "yevmiye" adı verilen günlük ücretlerine dair kayıtlar yer almıştı. Bunun yanında "ta'âmiyye", "in'âmât", "nafaka" adıyla yine gemi yapım sürecinde görevli kişilere verilen ücretler, birtakım taşıma ve küçük çaplı malzeme alımları mevcuttu.

Tablo 4: Birecik’te Gemi İnşaatı Sırasında Ücretler Mukabilinde Yapılan Ödemeler

\begin{tabular}{|l|l|c|}
\hline $\begin{array}{l}\text { Satın Alınan Malzeme Yahut İş Gücü } \\
\text { Ödemeleri }\end{array}$ & $\begin{array}{l}\text { Miktarı/ } \\
\text { Kuruş }\end{array}$ & $\begin{array}{l}\text { “Ücûrât” Harcamaları } \\
\text { Içerisindeki Oranı }\end{array}$ \\
\hline $\begin{array}{l}\text { Demirci ücreti ve firkate ve sandallara } \\
\text { gerekli demir ve demirden yapılan ürünler } \\
\text { için yapılan ödeme }\end{array}$ & 4.530 & $5,5 \%$ \\
\hline Kereste nakli için hamallara ödenen ücret & $1.601,5$ & $2,0 \%$ \\
\hline Neccarlara ödenen ücret & $6.881,5$ & $8,4 \%$ \\
\hline Marangoz ücreti & 4.577 & $5,6 \%$ \\
\hline Kalafatçı ücreti & 2.274 & $2,8 \%$ \\
\hline $\begin{array}{l}\text { Mekkare ücreti (Marangoz ve kalafatçıları } \\
\text { taşımak için 22 bargirle) }\end{array}$ & 99 & $0,1 \%$ \\
\hline Makaracı ücreti & 430,5 & $0,5 \%$ \\
\hline Bıckıcı ücreti & 3.073 & $3,8 \%$ \\
\hline Kürekçi ücreti & 239,5 & $0,3 \%$ \\
\hline Katırcı ve arabacıların ücret ve harçlıkları & 226 & $0,3 \%$ \\
\hline $\begin{array}{l}\text { Yemek ücreti ve kerestelerin sorumluluğu } \\
\text { çerçevesinde ödenen ücretler }\end{array}$ & 366,5 & $0,4 \%$ \\
\hline $\begin{array}{l}\text { Reislere, kürekçilere, dümencilere, gemi } \\
\text { kirasına ödenen ücret ve kendir masrafi }\end{array}$ & $2.109,5$ & $2,6 \%$ \\
\hline
\end{tabular}




\begin{tabular}{|l|l|c|}
\hline $\begin{array}{l}\text { Mimar, emin, amele, kâtip ücretleri ve } \\
\text { kerestelerin saklanması için ödenen ücret }\end{array}$ & $2.242,5$ & $2,7 \%$ \\
\hline $\begin{array}{l}\text { Baltacılara, mimarlara (marangozlara) tüm } \\
\text { masraflarıla birlikte ödenen ücretler ve } \\
\text { kerestelerin nakli ile ilgili ödenen ücretler }\end{array}$ & $30.717,5$ & $37,6 \%$ \\
\hline $\begin{array}{l}\text { Baltacılara, mimarlara (marangozlara) tüm } \\
\text { masraflarıyla birlikte ödenen ücretler ve } \\
\text { kerestelerin nakli ile ilgili ödenen ücretler }\end{array}$ & 9.244 & $11,3 \%$ \\
\hline $\begin{array}{l}\text { Baltacılara, mimarlara (marangozlara) tüm } \\
\text { masraflarıyla birlikte ödenen ücretler ve } \\
\text { kerestelerin nakli ile ilgili ödenen ücretler }\end{array}$ & 2.628 & $3,2 \%$ \\
\hline $\begin{array}{l}\text { Baltacılara, mimarlara (marangozlara) tüm } \\
\text { masraflarıyla birlikte ödenen ücretler ve } \\
\text { kerestelerin nakli ile ilgili ödenen ücretler }\end{array}$ & 2.603 & $3,2 \%$ \\
\hline Salların masrafi için ödenen ücret & 1.349 & $1,7 \%$ \\
\hline $\begin{array}{l}\text { Demirci karhanesinin onarımı için ödenen } \\
\text { ücret }\end{array}$ & 113,5 & $0,1 \%$ \\
\hline Muhtelif aletlerin ücret ve kirası & 157 & $0,2 \%$ \\
\hline Mübaşir ve bazı kişilerin harcırah ücreti & 964,5 & $1,2 \%$ \\
\hline $\begin{array}{l}\text { Mimar, kalafatçı ve keresteleri taşıma } \\
\text { işinde görevlilere “in‘âmât” adılla yapılan } \\
\text { ödeme }\end{array}$ & 465 & $0,6 \%$ \\
\hline $\begin{array}{l}\text { Donanma kethüdası Murad Kaptanın } \\
\text { ulufe ve nafakası }\end{array}$ & 744 & $0,9 \%$ \\
\hline Abdurrahman Ağa'ya ödenen meblağ & 3.000 & $1,0 \%$ \\
\hline $\begin{array}{l}\text { Kerestelerin korunmasında görevli } \\
\text { 1rgatların, mimar ve Mehmed Kaptan gibi } \\
\text { bazı görevlilerin yemek bedeli }\end{array}$ & 195 & \\
\hline $\begin{array}{l}\text { Baltacılara, kürek yapımında çalışan bazı } \\
\text { ustalara, mübaşirlere ödenen ücret ve } \\
\text { taşıma ücreti }\end{array}$ & 829 & \\
\hline Toplam & 81.66253 & \\
\hline
\end{tabular}

Kaynak: BOA, MAD, 5433, ss. 5-10; BOA, D.BŞM, 964, ss.4-6; BOA, D.BŞM. TRE, 14598, ss. 7-8.

53 Bu kaynaklardaki toplam rakamdır. Tablodaki rakamların toplamı 81.660 esedi kuruştur. Yani toplama yapılırken masraflar 2 kuruş fazla gösterilmiş yahut 2 kuruşluk bir hata yapılmıştır. 
Tablodan da anlaşlacağı üzere Abdurrahman Ağa'nın "el-ücûrât” başlığı çerçevesinde sarf ettiği toplam tutar 81.662 esedi kuruştu. Nitekim ilgili tutar toplam harcama tutarının \%76,6'sına, Abdurrahman Ağa'nın toplayabildiği gelirlerin ise \%88,4'üne tekabül etmişti. "Ücûrât” başlığı altında en yüksek harcama 45.192,5 esedi kuruş ödenerek kereste kesimi ve nakli çerçevesinde yapılan harcamalar oluşturmuştu. Bu tutar "ücûrât" başlı̆ğ altında yapılmış toplam harcamaların oransal olarak \%55,3'üne karşılık gelmişti. Kereste kesimi Malatya ve Maraş’ın ormanlık kesimlerinden yapılmıştı. Bu tutar içinde en dikkat çeken rakam 30.717,5 esedi kuruşla Maraş eyaletine bağlı Gökçemağara nahiyesinin dağlık alanlarından kesilmişti. Kesilen keresteler deve, katır ve öküz arabalarıyla Murat Nehri yanında yer alan Rumkale’ye ve Süpürgönc'e nakledilmişti. Maraş kadısının mübaşeretinde kerestelerin kesimi için baltacı ve onları yönlendiren mimarlara yevmiye ve ta'âmiye, taşıma için nakliye ücretleri ödenmişti ${ }^{54}$. Maraş'ta yapılan bir diğer kesim, Maraş’ın Yenicekale kazasının dağlık alanlarında vuku bulmuştu. Ne var ki buradan temin edilen ağaçlar diğer kerestelerden farklıydı ve gemi inşa işinde farklı bir işlevi vardı. Öyle ki "köknar çam"ından elde edilen bu kerestelerden gemilerin sütunları ve serenleri ${ }^{55}$ yapılacaktı. Sütunların uzunluğu 18 zira (13,5 metre), serenlerin ise 14 zira (10,5 metre) olacaktı. Köknar çamından elde edilen bu keresteler mekkare ve öküz arabalarıyla önce Maraş’a, oradan ise Murat Nehri yakınlarında bulunan Süpürgönc'e taşınmıştı. Süpürgönç’ten ise sallarla Birecik'e nakledilmişti. Tüm bu işten sorumlu olan Maraş kadısı, Abdurrahman Ağa'nın gönderdiği 2.628 esedi kuruşla kesim ve nakliye ücretlerini ödemişti ${ }^{56}$. Maraş eyaletine bağlı yerlerden yapılan son kereste tedariki, "Arslanlı beli" olarak bilinen bölgenin yukarısındaki -kaynakta "Cebel-i Hudi” olarak belirtilmiş- dağlık alandan sağlanmıştı. Buradan temin edilen kereste yine özel bir amaç için istenmişti. Buna göre bölgeden, inşa edilen gemilerin kürek ihtiyacının karşılanması için gürgen ağacından küreklik kereste kesimi yapılmıştı. Bu çerçevede firkateler ve baştardada kullanılmak üzere toplam 1.860 adet; sandallar, filika ve piyade kayıklarında kullanılmak üzere 220

BOA, MAD, 5433, s. 8; BOA, D.BŞM, 964, s. 5; Cumhurbaşkanlığı Devlet Arşivleri Başkanlığ1 Osmanlı Arşivi (BOA), Bâb-ı Defteri, Başmuhasebe Tersane-i Amire Defterleri (Bundan sonra D.BŞM.TRE), 14598, s. 7.

55 Seren, silindir biçiminde uzun ve kalın çam ağacına verilen bir isimdir. Bir diğer alternatif okunuşu serek ise, üzerine kare yelkenler açılmak üzere direklere ortasından yerleştirilen ağaca verilen bir isimdir. Parlatır, a.g.e., s. 1490.

56 BOA, MAD, 5433, s. 8; BOA, D.BŞM, 964, s. 5; BOA, D.BŞM.TRE, 14598, s. 7. Öğ̈üt, çalışmasında benzer bilgileri küçük hatalarla vermesine karşın, kaynağın sayfa numarasını yanlış belirtmiştir. Bkz. Öğüt, a.g.e., s. 256. 
adet; üstü açıklarda kullanılmak üzere 64 adet; toplamda 2.144 adet kürek gürgen ağacından kesilerek yapılmıs; kürekler mekkareler ile Birecik'e nakledilmişti. Ayrıca bu iş için her bir deveye 1,5 kuruştan toplam 1.608 esedi kuruş ödenmişti. Yine bu iş çerçevesinde 995 kuruşluk diğer ödeme, kesimi yapan baltacıların ve mübaşir Mehmed Efendi'nin yevmiye ve ta'amiyye ücretleriydi57 ${ }^{5}$. Gemilerin inşası için gerekli kerestenin temin edildiği bir diğer önemli yer Malatya sancağıydı. Malatya sancağının "Karabehislü" (muhtemelen Behisni) kazasının "Karanludere" mevkiinde baltacı ve mimarlar vasıtasıyla büyük miktarda kesim yapılmıştı. Rişvanzade Halil'in nezaret ettiği kesimde, keresteler, mekkare davarlarıla Murat Suyu yakınlarında olan Kızılin ve Zindehor'a nakledilmişti. Tüm bu işler için yevmiye, ta'amiyye ve nakliye adı altında 9.244 esedi kuruş ödenmişti ${ }^{58}$.

"Ücûrât" başlı̆̆ı altında marangoz, bıçkıcı, kalafatçı, makaracı gibi gemilerin yapım sürecinde görev alan personele ödenen tutar, bir diğer dikkat çekici rakamdır. Buna göre 21.511,5 kuruş olan bu meblağ, toplam harcama tutarının \%20,18’ini, ücûrât başlığı altındaki harcamalarınsa \%26,34'ünü teşkil etmişti. Personele ödenen rakam içerisinde en büyük tutar 6.881,5 esedi kuruş ile neccerlara ödenmişti. Gemi inşa işinin temel işçileri olan neccarların büyük kısmı Birecik dışındaki yerlerden temin edilmişti. Bu çerçevede en fazla neccar, 87 nefer ile Abdurrahman Ağa'nın görevli bulunduğu Halep’ten getirilmiş; ancak bu neccarların temini farklı zamanlarda gerçekleştirilmişti. Öyle ki en uzun süre görev yapan grup 28 Ocak 1700 ile 1700 yılının Ağustos ayının ortalarına (7 Şaban 1111 ile 1112 yılının Safer ayının sonuna) kadar toplam 200 gün çalışan 22 kişilik gruptu. Bunun dışında 10 Şubat 1700 (20 Şaban 1111) tarihinde başlayıp 187 gün görev yapan 24 kişilik bir başka neccar grubu daha mevcuttu. Halep'ten gelen diğer neccar grupları ise 97 gün çalışan 18 kişilik, 8 gün çalışan 22 kişilik gruplardan ve 78 gün çalışan bir kişiden müteşekkildi. Halep’ten gelen neccarlara günlük ödenen yevmiye tutarı 30 akçeden ibaretti. Halep'ten gelen neccarlar dışında en kalabalık grup Ayıntab'tan gelen 68 kişilik bir neccar topluluğuydu. Ayıntab'tan gelen bu grup yine günlüğü 30 akçe yevmiye karşılığ 1 Mart 1700 ile 1700 yllının Ağustos ayının ortalarına (10 Ramazan 1111 ile 1112 Safer ayının sonuna) kadar toplam 168 gün hizmet

57 BOA, MAD, 5433, s. 8; BOA, D.BŞM, 964, s. 5; BOA, D.BŞM.TRE, 14598, s.8. Öğüt, çalışmasında aynı belgeye dayanarak kürek yapımı için kullanılan ağacın gürgen değil, karaçam olduğunu ifade etmiştir. Ayrıca küreklerin bir kısmının Bağdat ve Basra'ya gönderildiğini belirtmiş̧tir. Lakin referans olarak kullandığı belgede bu bilgiler mevcut değildir. Bkz. Ögüut, a.g.e., ss. 256-257.

58 BOA, MAD, 5433, s. 8; BOA, D.BŞM, 964, s. 5; BOA, D.BŞM.TRE, 14598, s. 7. 
vermiş̧i. Maraş'tan gelen 22 kişi bir diğer dikkati çeken neccar grubuydu. Bu grup 9 Mart 1700 ile 26 Temmuz 1700 (18 Ramazan 1111 ile 9 Safer 1112) arasinda toplam 140 gün hizmet etmişti. Diyarbakır'dan gelen 16 kişilik neccar taifesi ise 1700 Şubatından 1700 Temmuzunun 24. gününe (1111 Ramazanından 1112 Saferinin 7. gününe) kadar 155 günlük çalışışlardı. Bunlar dışında adı geçen bu üç bölgede yahut bu yerlere yakın çevrelerden 7 neccar daha görevlendirilmişti. Neccarlara verilen yevmiye istisnasız günlük 30 akçaydı. Bu gruplar dişında Kilis’ten 204 günlük çalı̧san 4 neccar, Ruha'dan 77 günlük hizmet veren 9 neccar daha mevcuttu. Son olarak gemilerin yapıldığı Birecik'ten toplam 8 neccarın hizmetine başvurulmuştu ${ }^{59}$. Birecik'te gemi yapımında toplam 221 neccar görev yapmıştı. Bunun yanında farklı bölgelerden farklı zamanlarda gemi yapım işinde görev verilen neccarlara aynı ücret verilmesi, neccarların bu süreçte basit işler yaptığı düşüncesini doğurmaktadır. Ayrıca neccarların gemi yapım işinin 300 günlük sürecinde maksimum 200 ortalama ise 150 günlük periyotta görev alması, tam kapasite ise 100 gün çalışması dikkat çeken noktalardandı. Anlaşılacağı üzere Ocak ayının sonlarına (Şaban ayına) kadar Birecik'e malzeme tedariki sürmüş, Ocak ayının sonlarından (Şaban ayının başından) itibaren gemilerin inşası başlamış ve 1700 yilının Ağustos ayının ortalarında (1112 Safer ayının sonunda) neccarlara düşen vazife bitmiş, yani gemiler büyük ölçüde tamamlanmıştı.

Neccarların ardından gemi yapım işinde çalışan ve en fazla ücret ödenen grup 4.577 esedi kuruş ile marangozlardı. Gemi inşa işinde daha kalifiyeli sanatkârlar olarak nitelenen marangozların ${ }^{60}$ büyük kısmı İstanbul'da tersanede görev yapan ustalardan temin edilmişti. Nitekim bu çerçevede 70 marangoz İstanbul'dan Birecik'e gönderilmişti61 ${ }^{6}$ Tipkı neccarların çalışırılmasında olduğu gibi marangozların iş takvimi de farklıydı. Marangozların hepsi aynı anda işe başlamamışı. Lakin marangozların neccarlardan en önemli farkı bir kısmının uzmanlıklarına göre farklı işlerde istihdam edilmiş olması ve ustalıklarına göre farklı ücretler almış olmalarıyd. Nitekim "ser-mimar" olarak tanımlanan iki kişiye günlük 120 akçe yevmiye ödenmiş̧i ki bu miktar en yüksek yevmiye ücretiydi. Bu kişilerden biri 17 Şubat 1700'den Ağustos ayının ortalarına (27 Şaban 1111 ila 1112 Safer ayının sonuna) kadar 180 gün, diğeri 1700 Ağustos/Eylül (1112 Rebî́ülevvel) ayı

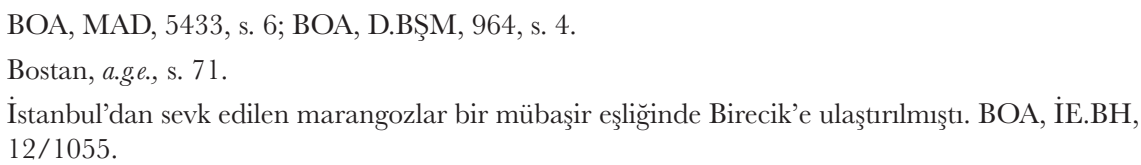
$12 / 1055$ 
içerisinde 17 gün istihdam edilmişti. İstanbul'dan gelen marangozlar içerisinde 11 Aralık 1699'dan 1700 Ağustos ayının ortalarına (18 Cemaziyelahir 1111 ile 1112 'nin Safer ayının sonuna) kadar görev yapan 19 kişilik bir grup dikkati çekmektedir. Bu tarihler arasında çalışan marangozlardan bir kişi 60 akçe, 2 kişi 50 akçe, bir kişi 43 akçe ve 15 kişi 40 akçe yevmiye almıştı. Bunun yanında firkate inşasında 15 marangoz 180 gün, 18 marangoz 113 gün ve 4 marangoz 111 gün yine 1700 Ağustosunun ortalarına (1112 Safer ayının sonuna) kadar 40 akçe yevmiyeyle hizmet vermişlerdi. "Açukha-yı kapudân" olarak ifade edilen gemide (yahut gemilerde) ise toplam 22 marangoz 40 akçe yevmiye ile 10 gün çalısmışlardı. İstanbul'dan gelen marangozlar dışında Trablusşam ve Sayda'dan toplam 30 ve Halep’ten 2 kişi gemi yapımı için istihdam edilmişti. Bunlardan 14'ü, 13 günlük bir periyotta "açukhâ-yı kapudân paşa" olarak ifade edilen geminin yapımı için 45 akçe yevmiye ile çalışmıştı. Firkate inşasında çalışanlar ise 9 Ocak 1700 ile 1700 Ağustosunun ortalarma (18 Receb 1111 ile 1112 Safer'inin sonuna) kadar 40, 45 ve 50 akçe yevmiyelerle toplam 219 günlük zaman diliminde görev almışlardı ${ }^{62}$. Çalışma sürelerinden anlaşıldığı kadarıyla marangozların çoğu firkate inşasında görev almış ve firkatelerin yapımı Ağustos ayının ortalarında büyük ölçüde bitmişti. Ayrıca marangozlara yapılan ödemelerden, neccarlara oranla gemi yapımında daha kalifiyeli personel oldukları anlaşılmaktadır. Özellikle İstanbul'dan gelen ve 120 akçe yevmiyeyle çalışan 2 kişinin bu tarz gemilerin yapımında ince işçilikten anlayan yahut mühendislik kısmını bilen ustalar olduğunu düşündürmektedir. Özellikle bu personelin yoğunlukla İstanbul'dan ve Birecik dışından gelmesi ise gemi yapımı işinde dikkat çekici bir diğer husustur. Nitekim Birecik'te bu ebattaki gemileri inşa edecek ustaların olmaması, buradaki gemi yapım işinin gelişmişliğini sorgulatan bir başka durumdu.

Birecik'te gemi yapım sürecinde bir diğer önemli ödeme "errekeş" de denilen ve kerestelerin ölçü üzere kesimi işini üstlenen ${ }^{63}$ bıçkıcılara yapılmıştı. Tıpkı neccarlar gibi bıçkıcılar da Birecik dışından sağlanmış, yani gemi inşa işinde çalıştırılan bıçkıcılar Halep, Ayıntab, Kilis ve Malatya'dan getirilmişti. Bıçkıcıların nereden hangi sayıda getirildiğine dair ayrıntı bulunmamakla birlikte, her biri 2 kişiden oluşan 45 kıta, yani 90 nefer bıçkıcı gemi yapımı için Birecik'te istihdam edilmişti. Bıçkıcıların çalışma süreleri de diğer görevlilerin çalışma süresine benzerlik göstermekteydi. Nitekim 19 Ocak 1700 ile 1700 Ağustosunun ortalarına (28 Receb

Bostan, a.g.e., s. 75. 
1111 ile 1112 Safer’inin sonuna) kadar görev yapmışlar ve yevmiye olarak 30 akçe ücret almışlardı ${ }^{64}$.

Tıpkı marangozlar gibi İstanbul, Trablusşam ve Sayda'dan gemi yapım işi için istihdam edilen bir başka grup kalafatçılardı. Birecik’te inşa edilen gemilerde çalışmak üzere kalafatçıların büyük kısmı, toplam 33 kişi, İstanbul'dan sevk edilmişti. Ne var ki bu 33 kişinin çalıştıkları süre, aldıkları yevmiye ve ustalıklarını gösteren unvanları farklı kaydedilmişti. Buna göre 40 akçe yevmiye ile 219 gün çalışan 1 kişi "burgucu", 50 akçe yevmiye ile 111 gün çalışan bir başka kişi "ser-kalafatçı" olarak kaydedilmişti. Geriye kalan 31 kişi ise 90 ila 219 gün arasında günlük 40 akçe yevmiye ile hizmet vermişti. Sayda ve Trablusşam'dan ise 8 kişilik iki farklı kalafatçı grubu gelmişti. Bunlardan uzun süreli çalışan grup, 9 Ocak 1700'den 1700 Ağustosunun ortalarına (18 Receb 1111 ile 1112 Safer'inin sonuna) kadar 7 kişi 40 ve 1 kişi 45 akçe yevmiye ile 219 günlük bir hizmet vermişti. Diğer 8 kişilik kalafatçı grubuysa 40 akçe yevmiyeyle sadece 10 günlük bir periyotta "açukha-yı kapudân" gemisinin (yahut gemilerinin) kalafatlanmasında görev almışlardı. Gemi inşası çerçevesinde mutad çalışan bu görevliler dışında dikkati çeken bir başka grup kürek ustalarıydı. Çektiri sınıfi gemilerin vazgeçilmez unsuru olan kürek ustaları da yine Birecik dışından İstanbul'dan getirilmişti. Buna göre 50 akçe yevmiye ile 266 gün, 40 akçe yevmiye ile 196 gün ve yine 40 akçe yevmiye ile 190 gün çalışmış 3 kürek ustası istihdam edilmişti. Bunun dışında toplam 10 adet makaracı çalıştırılmıştı. Bunların 4'ü Tersâne-i Âmire'den, 6'sı ise Birecik'ten sağlanmış; bu 10 makaracıdan 9'u 40 akçe yevmiye ile l'i ise 50 akçe yevmiye ile hizmet vermişti ${ }^{65}$.

Abdurrahman Ağa'nın yürüttüğü gemi inşa faaliyetinin harcama faslının ayrıntılarıyla aktarılmasının ardından finansal kayıtların genel bir değerlendirmesini yapabiliriz. İfade edildiği üzere Abdurrahman Ăga'nın gemi yapım sürecinde eline geçen toplam gelir 92.370 esedî kuruştan müteşekkildi. Ancak gemiler için gerekli malzemenin temini, taşıma ücretleri ve çalışanlara verilen ücretlerin toplamı 106.586,5 esedi kuruştan ibaretti. Anlaşılacağı üzere Abdurrahman Ağa 14.216,5 esedi kuruşu kendi gelirinden harcayarak gemilerin yapımını tamamlamış ve bu durumu belirterek ilgili tutarı miriden talep etmişti. Bunun dışında Abdurrahman Ağga arzında Birecik'te inşa edilen bir firkate ile İstanbul'da inşa edilen bir firkatenin muhasebesini de yapmıştı. Buna göre Tersâne-i Âmire'de yapılan firkate 1.255 
kuruşa, Birecik'te inşa edilen firkate 1.771 kuruşa mal olmuştu ${ }^{66}$. Öyle ki aradaki 516 kuruşluk fark Birecik'te inşa edilen firkatenin İstanbul'da inşa edilene göre \% 41,1 oranla daha masraflı olduğunu göstermekteydi. Abdurrahman Ağa'nın arzından anlaşıldığı kadarıyla bu farkın ortaya çıkmasındaki en önemli sebep, ana malzeme olan kerestenin uzaktan kestirilip nakledilmesiydi. Lakin Abdurrahman Ağa'nın izahında yer almayan, ancak hesaplarında görülen ve masrafları arttıran bir başka durum daha mevcuttu. Bu da gemi inşa işinde çalışacak usta ve personelin Birecik'te ya mevcut olmaması ya da yeterli sayıda bulunmamasiydı. Ayrıca Birecik'te yapılan gemilerin maliyetini daha çok yükselten başka hususlar da vard.. Mesela, Adana beylerbeyinin üstlendiği görevde olduğu gibi, inşaat için gerekli birtakım malzemeler yerel hazineler kullanılarak temin edilmişti. Nitekim bu gibi harcamalar gemilerin reel maliyetinin kayıtlarda görünenden daha yüksek olmasına neden olmuştu. Anlaşllacağı üzere firkatelerin inşası beklentilerinin üzerinde bir maliyetle gerçekleşmiş ve bu durum Abdurrahman Ağa tarafindan açıklanmaya çalısıılmıştı.

\section{Harekât Öncesi Son Aşama: Gemilerin Donatılması}

Abdurrahman Ağa'nın gemi inşa faaliyetini tamamlamasının ardından, özellikle büyük ölçekli gemilerin -firkatelerin- personel ve teçhizat bakımından eksikliklerinin giderilmesi gerekiyordu. Ne var ki bu işi yürütecek kişi Abdurrahman Ağa değildi. Incelenen belgelerden anlaşıldığı kadarıyla bu iş için vazifelendirilen kişi Şat Kaptanı olarak atanan Mehmed Paşa ve Bağdat Valisi Vezir Mustafa Paşa’ydı. Nitekim Şat Donanması için inşa edilen 60 firkatenin teçhizat, personel ve personelin görevi esnasında ihtiyaç duyduğu temel mühimmat Bağdat Kalesi'nin tahkimi için tutulan bir defterin içerisinde kayıtlı bulunmaktaydı ${ }^{67}$. Bunun dışında yine Kaptan Mehmed Paşa'ya Abdurrahman Ağa'nın gelirlerinden 10.150 kuruş verilmişti. Büyük ihtimalle bu meblağ gemilerin personel ve hareket için gerekli teçhizat eksikliğinin giderilmesi için kullanılmıştı; ancak belgelerden anlaşıldığı kadarıyla, gemilerin donatılması Birecik'te değil Bağdat'a uluşmasının akabinde gerçekleşmişti. Nitekim bunun sebebi daha önce de bahsettiğimiz bir soruna pratik bir çözüm bulmak kaygısından doğmuştu. Hatırlanacağı üzere Birecik'ten Fellüce'ye kadar olan suyolu dardı. Muhtemelen bu sebepten ötürü gemilerin daha hafif ilerlemesi ve ağır olan savaş teçhizatının Bağdat'ta yüklenmesi planlanmıştı.

Bkz. BOA, MAD, 975. 
Inşa planlarında belirtildiği gibi yapımı tamamlanan her bir firkate 70 nefer mürettebat ile teçhiz edilmişti. Bu çerçevede firkatelerde toplam 4.200 nefer görevlendirilmişti. Görev yapan bu personelin her bir gemi için ylllık (salyane) ödenen maaşları 3.000 kuruştu. Nitekim bu miktar toplamda 180.000 esedi kuruş tutmuş $^{68}$, diğer ödemelerle birlikte toplam ylllık personel gideri 220.000 esedi kuruşu bulmuştu ${ }^{69}$. Personel haricinde gemilerin hizmet verebilmesi için en önemli unsur askerî teçhizatla donatılmasıydı.

Tablo 5: Firkatelerin Teçhizinde Kullanılan Top ve Top Mühimmatı

\begin{tabular}{|c|c|c|c|}
\hline Mühimmatın Cinsi & Adet & Mühimmatın Cinsi & Adet \\
\hline Koğuş topu & 60 & Yan top & 120 \\
\hline Havan topu & 4 & Saçma (top) & 18 \\
\hline Eynek (top) & 24 & Timur-i saçma & 230 \\
\hline Timur-1 eynek & 472 & Kepçe (top) & 180 \\
\hline Maymuncuk-1 havata & 10 & Maymuncuk (0,5 vukiyye atar) & 94 \\
\hline Maymuncuk (100 dirhem & 26 & Maymuncuk-1 saçma & 12 \\
\hline atar) & 360 & Martine topu & 60 \\
\hline Sıyrık (top) & 60 & Muhtelif toplar & 180 \\
\hline İğne (top) & 60 & Havan danesi & 552 \\
\hline Sırık ve burgu & 18.000 & Havan kundağ & 4 \\
\hline Yuvarlak & 16 & Muhtelif kundaklar & 60 \\
\hline$?$ & & & \\
\hline
\end{tabular}

Kaynak: BOA, MAD, 975, s. 16

Belgedeki verilerden anlaşıldığı kadarıyla tabloda zikredilen top ve top mühimmatına dair malzemeler İstanbul'daki Tophâne-i Âmire'den Kaptan Mehmed Paşa'ya gönderilip teslim edilmişti. Firkatelere verilen toplar içerisinde en büyük ölçekli olanları havan toplarıydı. Ancak bu büyük kalibreli toplardan sadece 4 tane gönderilmişti ve gönderilen bu topların 2 tanesi 24 vukiyye atar kalibresindeydi. Diğer 2 tanesiyse sadece 14 vukiyye atardı. Ne var ki yapılacak gemilerin özellik-

6870 personelli bir firkateye 3.000 kuruş ve toplamda 180.000 kuruş salyane ödendiğine dair ayrıca bakınız. BOA, IE.BH, 10/908. Bu kayıtta ayrıca aynı tarihte Tuna'daki firkatelerin 81 nefer mürettebatla teçhiz edildiği ve her birinin yıllık mürettebat masrafinın 3.000 kuruş olduğu belirtilmişti.

69 BOA, MAD, 975, s. 15. 
lerini belirleyen heyet, her gemiye 2 tane 20 vukiyye atar topun konabileceğini ifade etmişti. Ancak tablodan anlaşllacağı üzere belirten ölçüde büyük topların her gemiye tahmili yapılmamış, bunun yerine gemilere daha küçük ölçekli çok sayıda topun yerleştirilmesi tercih edilmişti. Nitekim her bir firkateye 1 adet koğuş topu tahsis edilmişti. Bu koğuş toplarından 41 tanesi 1,5 vukiyye atar 19 adediyse 1 vukiyye atarlık toplard. Yine 1,5 vukiyye atar toplardan dikkati çekenlerden bir başkası "kepçe-i top" olarak kayda geçmiş bir toptu. Toplamda 180 adet olan bu topun 60 adedi 1,5 vukiyye, 90 adedi 0,5 vukiyye ve 30 adedi 100 dirhem (yaklaşık 300 gr) gülle atar silahlardı. Aynı şekilde "maymuncuk" ismiyle kaydedilmiş topun kalibresi 1,5 vukiyye, 0,5 vukiyye ve 100 dirhemlik mermiler atar biçimdeydi. Firkatelere gönderilen toplardan 120 tanesi "yan top" olarak adlandirılan ve geminin yanlarına konumlandırılan toplardand. Bu topların 92 adedi 0,5 vukiyye atar ve 28 tanesi 100 dirhem ağırlığında mermi atar nitelikteydi. Yan toplardan her gemiye iki adet konulmuştu ${ }^{70}$. Tophaneden büyük çaplı havan topları için 221 tane 24 vukıyyelik, 331 tane 14 vukiyyelik top mermisi verilmişti. Küçük toplar için ise 4.100 adet 1,5 vukiyye, 1.900 adet 1 vukiyye, 9.400 adet 0,5 vukiyye ve 2.600 adet 100 dirhemlik mermi gönderilmişti ${ }^{71}$. Anlaşılacağı üzere suyoluna göre gemilerin inşa planlaması yapılırken her bir gemiye 2 tane büyük kalibreli (ağır) top konulmasının belirtilmesi, geminin taşıma kapasitesine yapılmış bir işaretti. Lakin gemi inşa edildikten sonra her gemiye 2 tane büyük kalibreli top yerine çok daha küçük toplar tercih edilmişti. Bu sayede adet olarak planlanandan yaklaşı 4 kat daha fazla (1.910 adet) top yahut top olarak adlandırılan silah kullanılmıştı. Bunun muhtemel nedeni küçük topların yapılacak askerî harekâtta daha etkili yahut askerî harekâtın niteliğine daha uygun olmasıydı.

Özellikle firkatelerin top ve benzeri silahlarla donatılması yeterli değildi. Gemilerin aynı zamanda seyrüseferi esnasında ihtiyaç duydukları başka mühimmatlar da mevcuttu.

70 Birecik'te üretilen donanmaya tahsis edilen yan topların yuvarlak kalıplarının dökülmesi için 28 Şubat 1700/9 Ramazan 1111 tarihli kayıt mevcuttu. Buna göre bu kalıpların hazırlanması için Sertopçu Abdülkerim'e Tophâne-i Âmire mühimmatından 50 vukiyye $(64,1$ kg) ağırlığında bakır verilmesi istenmişti. BOA, İ.BH, 10/906. Bu üretimle ilgili bir başka ayrıntıysa, yine Abdülkerim'den -1 Mart 1700/10 Ramazan 1111 tarihinde- yan toplar için üretilmesi planlanan 12.000 adet yuvarlağın bir an evvel dökülüp, hazır edilmesinin ve bu iş için gerekli kömür, dökümcü, körükçü ve hamal ücret ödemelerinin yapılmasının istenmiş olmasıydı. Bkz. AE.SMST.II, 63/6649.

71 BOA, MAD, 975, s. 16. 
Tablo 6: Gemilerin Teçhizinde Kullanılan Diğer Mühimmat

\begin{tabular}{|c|c|c|c|}
\hline Mühimmatın Ginsi & $\begin{array}{l}\text { Adet }^{72} / \\
\text { Kantar }\end{array}$ & Mühimmatın Ginsi & $\begin{array}{l}\text { Adet/ } \\
\text { Kantar }\end{array}$ \\
\hline Mamûl alat-1 rişte & 305 (Kantar) & Lenger-i firkateha & 60 (Kita) \\
\hline Bâdbân-1 kalyon & 4 (Kıta) & Bâdbân-1 filika & 2 (Kita) \\
\hline Makara & 60 (Adet) & Fanus sagir ve kebir & 300 (Adet) \\
\hline İplik ve urgan & 2.000 (Adet) & Kinnab-1 resen & 60.000 (Adet) \\
\hline Kirpâs-1 bâdbân & 2.000 (Kita) & Fanus-1 kıç-1 mutallâ & 3 (Adet) \\
\hline Kurşun (gemiler için) & 98 (Kantar) & Kurşun (leventler için) & 300 (Kantar) \\
\hline $\begin{array}{l}\text { Keçe-i kebir (sargı ve barut } \\
\text { için) }\end{array}$ & 300 (Adet) & Balta-i neccarî & 175 (Adet) \\
\hline Mismâr & 60 (Kantar) & Levazımat-1 hartuç & 12 (Adet) \\
\hline Barut & 450 (Kantar) & Balta & 140 (Adet) \\
\hline Harbe & 240 (Adet) & Kazık & 4.000 (Adet) \\
\hline
\end{tabular}

Kaynak: BOA, MAD, 975, ss. 16-17.

Nitekim gemilerin nehirde hareketi sırasında ihtiyaç duyduğu bu mühimmatların büyük kısmı Tersâne-i Âmire'den gönderilmiş, bir kısmı Cebehâne-i Âmire'den sevk edilmiş, bir kısmı ise İstanbul'dan satın alınarak yollanmıştı. Buna göre tabloda yer alan ilk on malzeme Tersâne-i Âmire'den gönderilen mühimmattı ${ }^{73}$. Bu malzemeler gemilerin demirlemesinde kullanılan lenger ${ }^{74}$, çeşitli ebatlarda bâdbân (yelken) $)^{75}$, makara, fanus ${ }^{76}$, kap ve muhtelif ebatlarda ip ve urgandan müte-

72 Tabloda kaynağa sadık kalınarak adet ya da kıta kullanılmıştır.

73 Tahir Sevinç, Tersâne-i Âmire'den gönderilen on kalem malzemeyi farklı bir kaynak kullanarak "1699 Yılında İstanbul'dan Temin Edilen Bazı Malzemeler" adı altında bir tablo yapmışır. Lakin kullandığı kaynakta var olmasına rağmen okuyamadığı -bâdbân-ı kalyon, bâdbân-ı filika, fanus-1 kıç-1 mutallâ gibi- kalemlere oluşturduğu tabloda yer vermemiştir. Bunun yanında eksik ve tamamen yanlış okumalarda mevcuttur. Mesela "mamul alat-ı rişte"yi "alat-ı kayıl", "makarayı firkate"yi "eşya-yı firkate", "kirpâs-ı bâdbân-ı”ı sadece "kirpâs” şeklinde okumuştur. Sevinç, a.g.m., s.64. Fakat tüm bunların yanında asıl sorun yanlış kaynaktan eksik bilgi çıkarılmasıdır. Diğer örneklerde olduğu gibi Sevinç'in Abdurrahman Ağa'nın gemi inşa işine odaklanmayan çalışması bu süreci tam takip edememiştir. Dolayısıyla kaynaklar doğru analiz edilmeden ortaya konulan sondajlama veriler, bu örnekte de olduğu gibi, süreçle ilgili eksik ve yanıltıcı bilgileri ortaya çıkartmıştır.

74 Bostan, a.g.e., s. 151.

75 Parlatır, a.g.e., s. 140.

76 Fânus, mum, kandil gibi alevle yanan maddelerin ışığını rüzgârın söndürmesinden korumak için 
şekkildi. İstanbul'dan satın alınan malzemelerse gemi için kurşun, çeşitli ebatlarda muhtelif işler için lazım olan kumaş ve kese, gemilerin tamiri için kullanılacak balta ve çivi gibi Tersâne-i Âmire'den temin edilmeyen gemilerin sefer esnasında gerek duyduğu mühimmattı. Satın alınan altı kalemlik mühimmat arasında farklı olan tek kalem ise leventlerin kullanımı için temin edilen 300 kantarlık (16.920 $\mathrm{kg}$ ) kurşundu ${ }^{77}$. Benzer bir biçimde çatışma esnasında kullanılacak barut, balta ve harbeden oluşan üç kalemlik mühimmat Cebehâne-i Âmire'den gönderilmişti. Bu mühimmat içerisinde bulunan $450 \mathrm{kantar}(25.380 \mathrm{~kg})$ barutun 270 kantarı $(15.228$ $\mathrm{kg})$ top için $180 \mathrm{kantar}(10.152 \mathrm{~kg})$ ise tüfeklerde kullanılmak üzere verilmişti. Son olarak, tabloda görülen ve İstanbul'dan sevk edilmeyen tek malzeme 4.000 adet kazıktı. Bu mühimmat Rişvanzade Halil tarafindan Malatya'dan kestirilerek gönderilmişti ${ }^{78}$. Anlaşıldığı kadarıyla tabloda yer alan bütün bu levazımatın büyük kısmı firkatelerin teçhizinde kullanılmıştı. Ve yine anlaşılan bir diğer bariz durum, gemilerin seyrüseferi için gerekli mühimmatın çoğunun İstanbul'dan satın alınmış yahut tersaneden sevk edilmiş olmasıydı. Nitekim, tüm verilerin bize gösterdiği Birecik'te bu ölçekteki gemilerin olağan şekilde yapılmadığıdır. Eğer firkate ölçeğinde yahut bu gemilere yakın ebatlarda gemiler inşa edilmiş olsaydı, gemilerin ihtiyacı doğrultusunda gerekli malzemelerin yapımı çerçevesinde bir sanayi veya gerekli mühimmatın temini hususunda bir ticaret unsuru gelişmiş olurdu. Bu durumda gemilerin ihtiyaç duyduğu mühimmatın en azından bir kısmı Birecik'ten yahut yakın bölgeden sağlanabilirdi.

Gemilerin inşasının tamamlanması, silah ve diğer levazımının tedarik edilmesinin ardından geriye, görev esnasında neferlerin temel iaşe gereksinimlerinin giderilmesi işi kalmıştı. Osmanlı Devleti'nin donanma personelinin denizde iken temin etmek durumunda olduğu temel iaşe maddesi su ve peksimedden ibaretti. Su, gemilere yerleştirilen varil yahut kaplara uygun bölgelerden depolanmasıyla sağlanırken, asıl külfeti oluşturan ve tedariki daha zor olan gida maddesi peksimeddi ${ }^{79}$. Öyle ki bu durum Birecik'te inşa edilen firkateler için de geçerliydi.

etrafını kuşatan camdan yapılma kap bir kaptır. Bostan, a.g.e., s. 153.

77 BOA, MAD, 975, s. 16.

78 BOA, MAD, 975, s. 17.

79 Bostan, a.g.e., s. 244. 
Tablo 7: Firkate Neferleri İçin Temin Edilen İaşe Mühimmatı

\begin{tabular}{|c|c|c|c|}
\hline \multirow{2}{*}{ Temin Edildiği Yer } & İaşe Mühimmatının & \multicolumn{2}{c|}{ Miktarı } \\
\cline { 3 - 4 } & Türü & Kantar & Kile \\
\hline Halep & Peksimed & 6.000 & - \\
\hline Ayıntab & Peksimed & 1.500 & - \\
\hline Rakka ve Birecik & Buğday & - & 6.250 \\
\hline \multicolumn{2}{|c|}{ Toplam } & $\mathbf{7 . 5 0 0}$ & $\mathbf{6 . 2 5 0}$ \\
\hline
\end{tabular}

Kaynak: BOA, MAD, 975, s. 17.

Öncelikle ifade edilmesi gereken nokta, inşa edilen 98 gemi için değil, büyük ölçekli olan ve askerî harekâtta rol alan firkate personeli için peksimed tedarikinin planlandığıdır. Nitekim tablodan da anlaşıldığı üzere gemilerin yapıldığı bölgeden yahut yakın çevreden peksimed ve buğday tedarik edilip gemi neferlerinin iaşesi için kullanılması öngörülmüştü. Neferler için gerekli peksimedin büyük kısmı Halep'ten tedarik edilmişti. Ayrıca Antep'ten de önemli miktar peksimed sağlanmıştı. Lakin dikkat çeken husus Rakka ve Birecik'ten tedarik edilen 6.250 kilelik $(160.000 \mathrm{~kg})^{80}$ buğdaydı. Belgeler incelendiğinde bu yerlerden de ilk olarak peksimed talep edildiği anlaşılmaktadır. Nitekim Rakka'dan 1.000, Birecik'ten ise 1.500 kantar olmak üzere toplam 2.500 kantar (141.000 kg) peksimed talep edilmişti. Ne var ki sebep gösterilmeden bu miktar yerine 6.250 kile (160.000 kg) buğday alınmışt ${ }^{81}$. Anlaşılan bu bölgelerden her bir kantar peksimed yerine 2,5 kile buğday istenmişti. Nitekim bu miktar gemi neferatı için tedarik edilen 1 kantar peksimedin yapılması için standartlaşmış buğday miktarıydı ${ }^{82}$. Buradan hareketle bir hesaplama yapılacak olursa, Birecik'te yapılan 60 firkatenin nefaratının ihtiyaçları için 10.000 kantar $(564.000 \mathrm{~kg}$ ) peksimed yahut peksimed pişirmek için buğday temin edilmişti.

Toplanan peksimedlerin firkate neferlerine tevziatına bakılacak olursa, öncelikle -belgelerden tespit edildiği şekliyle- firkatelere zahire dağıtımının Bağdat'tan yapıldığı anlaşılmaktadır. Buna göre her bir nefer için öngörülen peksimed miktarı 0,5 (0,641 kg) kıyye/vukiyyedir. 60 gemide toplam 4.200 personel için günlük

801 Kilenin standart miktarı 25,659 kg'dır. Cengiz Kallek, "Kile”, DİA, C. 25, TDV. Yay., İstanbul 2002, s. 569; Halil İnalcık, Osmanh İmparatorluğunun Sosyal ve Ekonomik Tarihi (1300-1600), C. I, Çev. Halil Berktay, Eren Yay., İstanbul 2000, s. 444.

81 BOA, MAD, 975, s. 17.

82 Bostan, a.g.e., s. 245. 
gerekli miktar $2.100(2.692 \mathrm{~kg})$ klyyeydi. Bu gemiler toplamda 177 gün seferde bulundukları için gerekli olan peksimed miktarı 378.000 (484.596 kg) kıyyeydi. Nitekim bu miktarın 268.000 kıyyelik yani 6.090 kantarlı (343.476 kg) kısmı Halep ve Antep’ten peksimed olarak alınan mühimmattan sağlanmıştı. Geriye kalan 110.000 kıyyelik (141.020 kg) kısmı ise Rakka ve Birecik'ten temin edilen buğdayın un haline getirilmesiyle sağlanmıştı. Belgede unun ne şekilde peksimede çevrildiğine dair açıklama bulunmamaktadır. Ancak sefer halinde gemilerde bu unun ekmeğe yahut peksimede çevirme ihtimali düşük olduğundan, gemilere dağttılmadan evvel Bağdat'ta pişirildiği düşünülebilir. Rakamlardan da anlaşılacağı üzere sefer esnasinda yapılan tevziatın ardından, toplanan peksimed ve undan bir miktar bakiye kalmıştı. Öyle ki bu miktar 1.409 kantar $(79.468 \mathrm{~kg}$ ) peksimed ve 750 kile $(19.200 \mathrm{~kg})$ undan ibaretti ${ }^{83}$. Belgelerden çıkartılan bu verilerin dışında, ilgili peksimed ve buğdayın/unun hangi finansmanla yahut yöntemle temin edildiği, bu bölgelerden Bağdat'a nasıl sevk edildiği bilgileri yer almamaktadır. Bu nedenle gemilerin sefer esnasında ortaya çıkan mali yükü hesaplanamamıştır.

Gemilerin inşasının bitirilmesi ve teçhizatın tamamlanmasının ardından Kaptan Mehmed Paşa'ya "Şat Donanması" kaptanlı̆̆ payesi verilerek donanmanın başına tayin edildi ${ }^{84}$. Şat Donanması kaptanı olarak Mehmed Paşa'nın bu süreçteki ilk görevi, Basra'daki isyanı bastırmak için görevlendirilmiş olan Bağdat Valisi Daltaban Mustafa Paşa'nın direktifleriyle hareket etmekti. Kaynaklarda "Ziyab Seferi” olarak geçen ve Basra'da eşkıyalık yapıp, düzeni bozan Arap kabilelerinin tekidi sürecini içeren bu organizasyon, 20 Aralık 1701 (19 Receb 1113) senesinde son bulmuştu. Osmanlı kuvvetlerinin zayiat vermeden tamamladığı vurgulanan bu sefer sürecinde Fırat suyolunda da birtakım düzenlemeler yapılmıştı ${ }^{85}$. Her ne kadar Daltaban Mustafa Paşa üzerinden sefer anlatılsa da Birecik'te yapılan donanmanın başına geçen Aşçığlu Mehmed Paşa'nın da önemli faaliyetleri olmuştu. Kaptan Mehmed Paşa yapılan 60 adet firkateye ek olarak 1 adet üstü açlk gemisini küçük bir kalyona çevirmiş ve isyan halinde olan Arap kabilelerine karşı önemli başarılar kazanmıştı. Kaynağın ifadesiyle Mehmed Paşa'nın bu başarısı

BOA, MAD, 975, s. 17.

Mehmed Paşa'nın önceki görevi Tuna Kaptanlığıydı. Yapılan firkatelere "baş buğ" olarak atanmasının ardından, Sığla Sancağı ve Büyükdeğirmenlik Ceziresi’ndeki gelirlerinin yeterli olmaması ve gelir tahsisi için tevcih edilen bu yerlerin yeni görev yerine uzak olmasından dolayı, Mehmed Paşa'ya 5 yüklük yeni gelir verilmesi istenmişti. Cumhurbaşkanlı̆̆ı Devlet Arşivleri Başkanlığı Osmanlı Arşivi (BOA), Ali Emiri, Mustafa II, (Bundan sonra AE.SMST.II), 6/525-1.

85 Topal, a.g.m., s. 78-79. 
10.000 askerle ancak sağlanabilirdi. Öyle ki Mehmed Paşa bu başarıyı sağlarken askeri beyhude yere yormamış ve devletin birkaç bin kese altın tasarruf etmesini sağlamış, seferdeki başarılarından dolayı Basra valiliğiyle ödüllendirilmişti ${ }^{86}$.

\section{4. İnşa Sürecinin Değerlendirilmesi: "Birecik'teki Gemi İnşa Faaliyetleri" Üzerine Düşünceler}

İfade edildiği gibi Osmanlı hâkimiyetine geçmesinin ardından Birecik’te gemi inşa faaliyetleri devam etmişti. Abdurrahman Ağa'nın Birecik'te yürüttüğü gemi inşa faaliyetleri, Birecik'in Osmanlı hâkimiyetine geçmesinin ardından yürütülmüş önemli bir gemi yapım projesiydi. Bu faaliyeti önemli kılan husus, inşa edilen gemilerin sayısından değil, ebatlarından ve fonksiyonundan kaynaklanıyordu. Öyle ki her biri 70 personeli ve ayrıca savaş teçhizatını taşıyabilecek büyüklükte 60 adet firkate Birecik'te inşa edilmişti. Öyleyse gerçekleşen bu gemi inşa faaliyetinin, Birecik'te vuku bulan olağan yahut önceki -askerî amaçl- inşa faaliyetleriyle kıyaslandığında durumu neydi? Nitekim bu soruya (kıyaslamaya) cevap ararken Birecik'in Osmanlı hâkimiyetine geçişinden ilgili zaman dilimine kadar Birecik'te gemi inşasından bahseden literatüre kabaca göz atmak faydalı olacaktır.

Osmanlı teşkilat tarihi yahut özellikle bahriye teşkilatı üzerine çalışan araştırmacılar, Basra'da yürütülen Osmanlı denizcilik faaliyetlerini desteklemek amacıyla, Birecik'te gemi inşa faaliyetlerinin yürütüldüğünü ifade etmişlerdi. Bu çerçevede ilk olarak 16. yüzyılın ikinci yarısından itibaren Birecik'te bir tersane kurulduğunu Uzunçarşılı belirtmiş ve bundan sonra Birecik'te tersane üzerinden gemi inşası yürütüldüğü kabul edilmiştir ${ }^{87}$. Uzuncarşlı'nın bir mühimme kaydına dayandırdığı bu bilgiye göre, Basra'da kullanılmak üzere Birecik'te 20 adet gemi (kalita) için önce kereste tedarik edilip sonrasında gemilerin inşası istenmişti. Lakin 10 adet gemiye yetecek kerestenin ancak toplandığı hükümde belirtilmiş ve bunun üzerine toplanan kerestelerle 8 adet geminin inşası talep edilmişti ${ }^{88}$. Ne var ki takip eden hükümlerde, bu ölçekte gemilerin Birecik'te inşa edilip Basra'ya sevk edilmesinin

Anonim Osmanl Tarihi, s. 221-222.

İsmail Hakkı Uzunçarşılı, Osmanlı Devleti’nin Merkez ve Bahriye Teşkilatı, TTK Yay., Ankara 1988, ss. 404-405. Osmanlı denizciliği ve teşkilatına dair sonraki çalışmamalarda, aynı şekilde Birecik'teki gemilerin mevcut tersanede inşa edildiğini ifade etmişlerdir. Bkz. Bostan, a.g.e., s. 21; Osmanl Teşkilat Tarihi El Kitabı, Ed. Tufan Gündüz, Grafiker Yay., Ankara 2012, s. 202; İdris Bostan, "İstanbul Dışındaki Osmanlı Tersaneleri ve Gemi İnşa Tezgâhları" Türk Denizcilik Tarihi, C. I, Editörler: İdris Bostan-Salih Özbaran, Deniz Basımevi Müdürlüğü Yay., İstanbul 2009, s. 318. BOA, MD, 3, s. 370, H.834 (8 Cemaziyülahır 967/ 6 Mart 1560).

Belleten, Ağustos 2020, Cilt: 84/Sayı: 300; 623-666 
mümkün olmadığı belirtilmiş ve tedarik edilen kerestenin 60 adet gemi/tekne ile Bağdat ve Basra'ya gönderilmesi istenmişti ${ }^{89}$. Bir bütünlük çerçevesinde bu hükümlere bakıldığında, dönem itibariyle mevcut koşullarda geleneksel taşımacılıkta kullanılan gemi, tekne, kelek ya da sandal dışında, daha büyük ölçekli su taşıtlarının Birecik'te yapılamayacağını işaret etmişti.

Uzunçarşlı'dan sonra, bu konuyla ilgili yapılan çalışmalarda Birecik'te özellikle askerî amaçla zaman zaman gemi inşa edildiği tekrarlana gelmiş, ${ }^{90}$ lakin yürütülen bu gemi inşa faaliyetinin ne ölçekli gemiler olduğu vurgulanmamıştı. Ne var ki yapılması istenen gemilerin inşa süreci yahut kullanım amacıyla ilgili çalışmalarda geçen açıklamalar, bu gemilerin ebatlarıyla ilgili tahminlerde bulunmamızı sağlamaktaydı. Mesela 1552 yllında eski Halep zaimlerinden Haydeddin'in nezaretinde 300 adet geminin inşası istenmişti. Açıklamalardan anlaşıldığı kadarıyla, her biri 60 sikkeye mal olan bu gemiler 10 nefer kürekçi ve 10 nefer cenkçi taş1yabilecek kapasitede, Firat suyolunda kullanılan olağan gemilerdendi ${ }^{91}$. Bir başka örnekte, 1565 tarihinde Canbolad Bey'den 400 adet geminin inşası talep edilmişti. Nitekim gemilerin ebadıyla ilgili bir bilgi bulunmamakla beraber inşa sürecinin kısalığından, bu gemilerin asker ve malzeme taşıma amacıyla yapılması planlandığından, nehir koşullarına uygun küçük ölçekli gemiler olduğu anlaşılmaktadır ${ }^{92}$. Yine Kuyucu Murad Paşa'nın Celali seferinde Bağdat'a yapılması planlanan bir askerî hareket için 100 adet geminin/teknenin tamiri bitirilmiş ve sefere hazır hale getirilmişti. Bağdat'a askerî malzemelerin nakliyatı için hazırlanan bu gemiler de muhtemelen Frat Nehri'nde kullanılan olağan teknelerdi ${ }^{93}$. 18. yüzyıla kadar geçen periyotta adet olarak dikkat çeken bir başka faaliyet 1638 Bağdat seferinde vuku bulmuştu. Bu seferin hazırlıkları esnasında ordunun ağırlıklarının

89 BOA, MD, 3, s. 377, H.849 (12 Cemaziyülahır 967/ 10 Mart 1560); BOA, MD, 3, s. 600, H.1355 (10 Zilkade 967/2 Ağustos 1560).

$90 \mathrm{Bu}$ tekrara Osmanlı deniz teşkilatı yahut nehir taşımacılığı üzerine yapılan çalışmalarda görülebildiği gibi Birecik tarihi üzerine kaleme alınan çalışmalarda da rastlanmaktadır. Bkz. Bostan, a.g.e., ss. 21-22; Orhonlu-Işıksal, a.g.m., s.83; Yılmaz, a.g.t., s. 168 vd.; Öğüt, a.g.e., s. 243 vd; Ali Yılmaz, "16. ve 17. Yüzyıllarda Fırat’ta Nehir Taşımacılı̆̆ı”, Göller ve Nehirler Sempozyumu Bildiri Kitabr, C. II, Kayseri 2015, s. 591.

91 Yilmaz, a.g.t., s. 168-169; Yılmaz, "Birecik'te Gemi İnsası”, s. 103-104.

92 Orhonlu-Işıksal, a.g.m., s. 92. Bu gemilerin inşasıı yaklaşık 5 ay sürmüştü. Nitekim Canbolad Bey'e gemi yapım emrinin 14 Ağustos 1565’te gönderilmesinden yaklaşı 5 ay sonra 150 geminin tamamlandığı geriye kalanların ise tamamlanmak üzere olduğu bilgisi alınmıştı. Yılmaz, a.g.t., ss. 172-173; Yılmaz, "Birecik'te Gemi İnsasi”, ss. 105-106; Sağırlı, a.g.m., ss. 56-58.

93 Topçular Kâtibi, Topçular Kâtibi Abdülkadir (Kadri) Efendi Tarihi, Haz. Ziya Yılmazer, C.II, TTK Yay., Ankara 2003, ss. 513-514. 
taşınması 600 geminin inşa edilmesi istenmişti. Anlaşılacağı üzere bahsedilen bu gemiler Fırat'ta mutat nakliye amaçlı kullanılan gemilerdi/sandallardı ${ }^{94}$. Belgelere yansıyan ve sayısı arttırılabilecek bu örnekler şunu göstermektedir ki ${ }^{95}$, özellikle olağanüstü zamanlarda merkezden Birecik'e gemi yapımına dair talepler gönderilmişti. Ancak bu örneklerdeki gemi taleplerinin hiçbiri Basra'da hizmete bulunmak için değil, genellikle Bağdat'a mühimmat ve asker nakletmek için yapılmış gemi talepleriydi. Sayı olarak Abdurrahman A ğa’nın yaptığı gemilerden çok daha fazla olmakla birlikte (inşa süreçlerinden anlaşıldığı üzere), bu gemilerin boyutları Abdurrahman Ağa'nın inşa ettiği firkatelerden çok daha küçük ebatlardaydı. Öyle ki Birecik'in gemi yapım kapasitesinden ${ }^{96}$, daha da önemlisi suyolunun özelliğinden dolayı belirtilen sayılarda büyük çaplı gemileri yapmak imkânsızdı ${ }^{97}$. Buradan hareketle Abdurrahman Ağa'nın yürüttüğü gemi yapım sürecini/projesini önemli kılan husus -bilinen örnekler dâhilinde- Osmanlı egemenliğinde girişinden sonra Birecik'te yapılan en kapsamlı inşa projesi olmasıydı. Nitekim Abdurrahman Ağa'da tuttuğu kayıtlarda Birecik'te “bu vakte kadar” firkate inşası olmadığını ifade ederek, bu ölçekte büyük gemilerin yapılmadığını, bu çerçevede bir proje yürütülmediğini vurgulamıştı ${ }^{98}$. Öyle ki tüm bu süreçteki verilerin incelenmesinden sonra ortaya çıkan düşünce, her ne kadar daha önceden talepler, girişimler olsa da, Abdurrahman Ağa'nın yürüttüğü bu inşa faaliyetinin Birecik'te üretilip Basra'da savaş gemisi olarak hizmet veren gemilere dair ilk örnekler olduğudur.

94 Yllmaz, a.g.t., s. 176. Tahsin Ünal bu süreçte inşa edilmesi istenen gemilerin sayısını 800 olarak belirtmiştir. Ünal, a.g.e., s. 57. "Lakin gemi yapım sürecine dair incelenen belgelerden, taşımacılık için hazırlanan gemi adedinin 645 olduğu anlaşlmaktadır. Bkz. Süleyman Polat, "IV. Murat Devri Doğu Seferlerinde Nehir Taşımacılığı ve 1638 Bağdat Seferinde Firat Üzerinden Yapılan Nakliyat", History Studies, 12/2, Nisan 2020, ss. 587-588."

95 Özellikle 16. Yüzylın ikinci yarısındaki bahsettiğimiz çerçevede gemi inşa taleplerine dair bkz. Yılmaz, a.g.t., ss. 168-178; Yılmaz, a.g.m., ss. 102-110. Yılmaz'ın çalışmasında Birecik'te yapılması emredilen gemilerin küçük sandallar olduğunu düşündürmeyecek tek örnek Ayas Paşa’nın 1545 tarihinde Basra Seferi esnasında kullanılan 120 gemiden oluşan donanmadır. Ancak buradaki gemilerin Birecik'te inşa edildiği ve büyük gemiler olduğuna dair söylemler yazarın yorumundan ibarettir. Bkz. Yılmaz, a.g.t., s. 168; Yılmaz, a.g.m., s. 103. Öyle ki aynı kaynağı kullanan farklı bir çalışmada bahsedilen gemilerin Birecik'te yapıldığına dair bir ifade yoktur. Bkz. Salih Özbaran, "XVI. Yüzyılda Basra Körfezi Sahillerinde Osmanlılar Basra Beylerbeyliğinin Kuruluşu”, TD, S. 25 (Mart 1971), İstanbul 1971, s. 56.

96 Çalışmada da ifade edildiği üzere başta kereste olmak üzere tüm malzemeler Birecik'e dişardan taşmıyordu. Ayrıca bu konuyu daha geniş bir zaman diliminden ele alan bir başka kaynak için ayrıca bkz. Orhonlu-Işıksal, a.g.m., ss. 80-83.

97 Belirtilen rakamlarda (300-600 adet) büyük ölçekli gemi yapımını imkânsız kılan bir başka husus kısitl zaman ve paraydı. 


\section{Sonuç}

Zaman içerisinde değişim göstermekle birlikte Osmanlı Devleti geniş sınırlara ve birbirinden farklı sosyal ve beşeri unsurlara sahipti. Bu farklılıklarla ilintili olarak Osmanlı Devleti'nin sahip olduğu sınırları koruması adına siyasî, askerî ve malî çözümler bulması zaruriydi. Nitekim Abdurrahman Ağa'nın Birecik’te üstlendiği gemi inşa faaliyeti, Kutsal İttifak savaşlarının ardından ortaya çıan ve sınır güvenliğini tehdit eden iç meselelerden birine çözüm arayışının bir ürünüydü. Sürece dair detaylarda görüldüğü üzere, Karlofça Antlaşması ile son bulan Kutsal İttifak savaşlarında önemli tecrübeler elde edilmiş ve daha da ilginci Tuna Nehri'nde kullanılan daha kolay mobilize olabilecek ebatlarda donanımlı, küçük çaplı savaş gemilerinin inşa edilmesi düşünülmüş̧ü. Bu durum 1700 yllında Abdurrahman Ağa'nın Birecik'te donanmanın inşasına başlanmasında etkili olacaktı.

Birecik'teki gemi inşasında kilit bir isim olan Abdurrahman Ağa'ya inşa sürecine dair tüm yetkiler ve malî yükümlülükler tevdi edilmişti. Onun seçilmesi de tesadüf değildi. Zira Halep Muhassılı olan Abdurrahman Ağa bölgedeki vergi toplama işine memur olmasından ötürü malzemelerin maliyetlerini bildiği gibi ilgili coğrafyadaki malî vaziyete en yakın gözlemciydi. Daha da önemlisi inşa sürecinde gerekli hazinenin bölgedeki hangi gelir kaleminden hangi oranda sağlanabileceği bilgisine de sahipti. Nitekim inşa süresinde gerekli paranın toplanmasında büyük aksaklıklar olmamış, ödemeler -Abdurrahman Ağa'ya devletin biraz borçlanması sonucunda olsa da- eksiksiz yapılmış, gemi inşası tamamlanmıştı. Gemi yapım sürecinde Abdurrahman Ağa'yı baskılayan birtakım etkenler de vardı. Nitekim genel literatür taramasından ve Abdurrahman Ağa'nın yazışmalarından anlaşlacağı üzere, bu zamana kadar Birecik'te bu ebatlarda gemi inşası gerçekleşmemişti. Bununla beraber Tuna ve İstanbul'daki firkate inşasının maliyeti, ilgili inşa süreci öncesinde önemli bir referans oluşturuyordu. Bu referans çerçevesinde Birecik'te inşa faaliyetlerine başlayan Abdurrahman Ağa, gemi yapım maliyetlerinin İstanbul'daki rakamlardan farklı biçimde yüksek olduğu gerçeğiyle karşı karşıya kalmıştı. Tuna'daki deneyim yanında zamanın beraberinde getirdiği teknik ilerlemeleri de kullanarak bir nehir donanması inşası fikri, bölgedeki yerel kontrol için gerekli ve faydalı görülmüssse de İstanbul ya da Tuna'dakinden \%41 daha yüksek maliyetli bir üretim, beklentinin üzerinde bir malî yük anlamına geliyordu. Kaldı ki inşa edilen firkateler Tuna'daki gemilere kıyasla daha küçüktü. Bu durum söz konusu inşa sürecinin gözden geçirilmesine neden olacak, bu işin sürekliliğiyle ilgili soru işaretleri oluşturacaktı. Anlaşılan tüm bu malî zorluklar, -yeni ve esnek seçenekler 
geliştirmesine karşın- Osmanlı Devleti’nin bölgedeki uzun vadeli var olma mücadelesindeki çözmesi gereken önemli sorunlardandı.

Abdurrahman Ağa'nın inşa süreci İmparatorluğun ilgili dönem içerisindeki malîidarî yapısını görmek açısından da önemli bir örnektir. Bu çerçevede, benzer yapıda olan sefer organizasyonlarında da karşımıza çıktığı üzere, devlet ilgili görevlendirmeleri zamanında yapıp işin ehli görevlileri inşa faaliyetine göndermişti. Görevlilerin maaş ve alacakları ücretler görev ve sorumlulukları kapsamında değerlendirilmişti. Kalifiyeli hizmet alımı dışında, basit hizmetlerin karşılanması ve mühimmat temini organizasyonu mümkün mertebe en yakın kişiden, en kısa mesafeden karşlanmaya çalışılmıştı. Bu doğrultuda iş gücü Trablusşam, Beyrut ve Sayda, kereste ve diğer mühimmat Maraş, Antep, Halep gibi Birecik'e yakın yerlerden temin edilmişti. Sürece dair önemli tespitlerden birisi de gemi inşasına girişmeden önce bazı hususlarda Birecik ileri gelenlerinin de fikirlerinin alınmasıydı. Bölgenin ileri gelenleri ve teknik sınıfin ortak kararı ile firkatelerin inşa edileceği yer Birecik'in güneyinde "Ala Kule" olarak tespit edilmişti. Bu gibi detaylar merkezi yönetimin, ortaya konulan organizasyonun ihtiyaçları çerçevesinde, esnek ve pragmatik çözümlerini göstermesi bakımından önemlidir.

Esas anlamda Abdurrahman Ağa'nın sorumluluğunda gerçekleşen Birecik'teki gemi inşa sürecinin oldukça kapsamlı kayıtları başından sonuna incelendiğinde, Osmanlı Devleti'nin merkez-taşra işleyişine, büyük bir yapım işinin idarî-malî detaylarına, bir nehir donanmasının teşkiline dair pek çok detaya ulaşılabilmektedir. $\mathrm{Bu}$ anlamda benzer nitelikteki çalı̧̧malarla beraber bu makaledeki detaylar, 17. yüzyılın sonu 18. yüzyılın başı Osmanlı idarî-malî mekanizmalarını anlamlandırmaya yardımcı olmaktadır. 


\section{KAYNAKLAR}

\section{Arşiv Kaynakları}

Cumhurbaşkanlığı Devlet Arşivleri Başkanlığı Osmanlı Arşivi (BOA):

Ali Emiri, Mustafa II ( AE.SMST.II):

AE.SMST.II, 6/525; AE.SMST.II, 63/6649.

Cevdet Bahriye (C.BH):

C.BH, 90/4305; C.BH, 149/7106.

İbnülemin Bahriye (IE.BH):

IEE.BH, 10/906; IEE.BH, 10/908; İE.BH, 10/913; IE.BH, 10/914; İE.BH, $12 / 1055$.

Bâb-ı Defteri, Başmuhasebe Defterleri (D.BŞM):

D.BŞM 964.

Bâb-ı Defteri, Başmuhasebe Tersane-i Amire Defterleri (D.BŞM.TRE):

D.BŞM.TRE, 14598.

Maliyeden Müdevver Defterleri(MAD):

MAD, 975, MAD, 5433, MAD, 9885.

Mühimme Defterleri (MD):

MD 3.

\section{Kitabî Kaynaklar ve Tetkik Eserler}

Anonim Osmanl Tarihi (1099-1116/1688-1704), Haz. Abdülkadir Özcan, TTK Yay., Ankara 2000.

Bostan, İdris, “Birecik”, DIA, C. 6, TDV. Yay., İstanbul 1992, ss. 187-189.

Bostan, İdris, "Gemi Yapımcilığı ve Osmanlı Donanmasında Gemiler" Türk Denizcilik Tarihi, G. I, Editörler: İdris Bostan-Salih Özbaran, Deniz Basımevi Müdürlüğü Yay., İstanbul 2009, ss. 325-339.

Bostan, İdris, "İstanbul Dışındaki Osmanlı Tersaneleri ve Gemi İnşa Tezgâhları" Türk Denizcilik Tarihi, G. I, Editörler: İdris Bostan-Salih Özbaran, Deniz Bası- 
mevi Müdürlüğü Yay., İstanbul 2009, ss. 311-321.

Bostan, İdris, Kürekli ve Yelkenli Osmanh Gemileri, Bilge Yayım Habercilik Yay., İstanbul 2005.

Bostan, İdris, Osmanlı Bahriye Teşkilâtı: XVII. Yüzynlda Tersâne-i Âmire, TTK. Yay., Ankara 1992.

Erkal, Mehmet, "Arşın”, DIA, C. III, TDV. Yay., İstanbul 1991, ss. 411-413.

Hınz, Walter, İslam'da Ölçü Sistemleri, Çev. Acar Sevim, Marmara Üniversitesi Yay., İstanbul 1990.

İnalcık, Halil, Osmanh İmparatorluğunun Sosyal ve Ekonomik Tarihi (1300-1600), G. I, Çev. Halil Berktay, Eren Yay., İstanbul 2000.

Kallek, Cengiz, "Kantar”, DİA, C. 24, TDV. Yay., İstanbul 2001, ss. 317-320.

Kallek, Gengiz, "Kile”, DIA, C. 25, TDV. Yay., İstanbul 2002, ss. 568-571.

Orhonlu, Cengiz - Işıkal, Turgut, "Osmanlı Devrinde Nehir Nakliyatı Hakkında Araştırmalar Dicle ve Frrat Nehirlerinde Nakliyat", İstanbul Üniversitesi Edebiyat Fakültesi Tarih Dergisi, S. 17-18 C. XIII, ss.77-102.

Osmanlı Teşkilat Tarihi El Kitabı, Ed. Tufan Gündüz, Grafiker Yay., Ankara 2012.

Ögüut, Tahir, 18 ve 19. Yy.'da Birecik Sancağmda Iktisadi ve Sosyal Yapr, TTK Yay., Ankara 2013.

Özbaran, Salih, "XVI. Yüzyılda Basra Körfezi Sahillerinde Osmanlılar Basra Beylerbeyliğinin Kuruluşu”, TD, S. 25 (Mart 1971), İstanbul 1971, ss. 51-72.

Parlatır, İsmail, Osmanlı Türkçesi Sözlüğü, Yargı Yay., Ankara 2006.

Polat, Süleyman, "IV. Murat Devri Doğu Seferlerinde Nehir Taşımacilığı ve 1638 Bağdat Seferinde Frrat Üzerinden Yapılan Nakliyat", History Studies, 12/2, Nisan 2020, ss. 577-593.

Sağırlı, Abdurrahman, "Cezâyir-i Irâk-1 Arab veya Şattü'l-Arab'ın Fethi -Ulyanoğlu Seferi- 1565-1571", Tarih Dergisi, S. 41, İstanbul 2005, ss. 43-93.

Sevinç, Tahir, “Osmanlı Devleti İdaresinde Birecik’te Gemi İnşası ve Birecik Tersanesinin Önemi (17. ve 18. Yüzyllar)" İslâm Tarihi ve Medeniyetinde Şanluufa: "Osmanh Belge ve Kaynaklarnda Urfa", G. IV, Şanlıurfa 2018, ss. 56-74. 
Silâhdar Findıklılı Mehmed Ağa, Nusretnâme Tahlil ve Metin (1106-1133/16951721), Haz. Mehmet Topal, Sosyal Bilimler Enstitüsü Türkiyat Araştırmaları Enstitüsü, Basılmamış Doktora Tezi, İstanbul 2001.

Streck, M., "Birecik”, IA. C. II, MEB Yay., İstanbul 1979, ss. 629-632.

Topal, Mehmet, "Bağdadlı Nazmî-zâde Murteza'nın İcmâl-i Sefer-i Nehr-i Ziyab Adlı Risalesine Göre Ziyab Seferi ve Nehirde Yapılan Düzenlemeler", Göller ve Nehirler Sempozyumu Bildiri Kitabı, C. II, Kayseri 2015, ss.71-83.

Topçular Kâtibi, Topçular Kâtibi Abdülkadir (Kadri) Efendi Tarihi, Haz. Ziya Yılmazer, C.II, TTK Yay., Ankara 2003.

Uzunçarşılı, İsmail Hakkı, Osmanh Devleti’nin Merkez ve Bahriye Teşkilatı, TTK Yay., Ankara 1988.

Ünal, Tahsin, IV. Murat ve Bağdat Seferi, Berikan Yay., Ankara 2001.

Yılmaz, Ali, "16. ve 17. Yüzyıllarda Firat'ta Nehir Taşımacilığı", Göller ve Nehirler Sетроzуити Bildiri Kitabr, C. II, Kayseri 2015, ss. 591-611.

Yılmaz, Ali, "Birecik'te Gemi İnşası", Uluslararası Türk Denizcilik ve Piri Reis Semроzyити 26-29 Eylül 2013, Türk Denizcilik Tarihi Bildiriler, 6. Cilt, TTK. Yay., Ankara 2014, ss.101-122.

Yılmaz, Ali, XVI. Yüzyılda Birecik Sancağı, İstanbul Üniversitesi Sosyal Bilimler Enstitüsü, Basılmamış Doktora Tezi, İstanbul 1996. 